\title{
Factors Contributing to an Efficacious Endovascular Treatment for Acute Ischemic Stroke in Asian Population
}

\author{
Jin Soo Lee, $\mathrm{MD}, \mathrm{PhD}^{1}$, Yang-Ha Hwang, $\mathrm{MD}, \mathrm{PhD}^{2}$, Sung-Il Sohn, $\mathrm{MD}$, $\mathrm{PhD}^{3}$ \\ ${ }^{1}$ Department of Neurology, Ajou University Hospital, Ajou University School of Medicine, Suwon, Korea \\ ${ }^{2}$ Department of Neurology, Kyungpook National University Hospital, School of Medicine, Kyungpook National University, Daegu, Korea \\ ${ }^{3}$ Department of Neurology, Keimyung University Dongsan Hospital, Kyemyung University School of Medicine, Daegu, Korea
}

\begin{abstract}
Although randomized control trials about endovascular treatment (EVT) of emergent large vessel occlusion (LVO) have demonstrated the success of mechanical thrombectomy as the choice of treatment, a wide range of caveats remain unaddressed. Asian patients were rarely included in the trials, thereby raising the question of whether the treatment could be generalized. In addition, there remains a concern on the feasibility of the method with respect to its application against intracranial atherosclerosis (ICAS)-related LVO, frequently observed in the Asian population. It is important to include evidence on ICAS LVO from Asian countries in the future for a comprehensive understanding of LVO etiology. Besides the issues with EVT, prognostic concerns in diabetes patients, acute kidney injury following EVT, neuroprotective management against reperfusion injury, and other peri-EVT issues should be considered in clinical practice. In the current article, we present an in-depth review of the literature that revises information pertaining to such concerns.
\end{abstract}

Key Words: Cerebral infarction; Endovascular procedures; Intracranial atherosclerosis; Diabetes mellitus; Acute kidney injury; Reperfusion injury

\section{INTRODUCTION}

Randomized control trials (RCTs) on endovascular treatment (EVT) have contributed to a considerable level of understanding, which must be drawn from when establishing specific treatment guidelines. Not all clinical studies can be done through RCTs because a prospective, multinational, multicenter study entails high costs that are required to ensure the safety of the participants. The success of several RCTs with respect to EVT against acute ischemic stroke (AIS) has contributed to a better prognosis of many patients around the world. However, Asians were rarely included in such RCTs for EVT, which led to doubts about whether these treatments could be generalized and used in Asian countries. In particular, mechanical thrombectomy (MT) involving the removal of a thrombus is unlikely to mitigate intracranial atherosclerotic stenosis (ICAS)-associated large vessel occlusion (LVO), which is widely prevalent amongst the Asian population. Interestingly, single-center or multicenter registry studies have suggested that the results of the research conducted in Western countries could

\section{Correspondence to: Jin Soo Lee, MD, PhD \\ Department of Neurology, Ajou University Hospital, Ajou University School of Medicine, 164 World- Cup-ro, Yeongtong-gu, Suwon 16499, Korea \\ Tel: +82-31-219-5173 \\ Fax: +82-31-219-5178 \\ E-mail: jinsoo22@gmail.com}

Received: September 20, 2020

Revised: February 11, 2021

Accepted: February 19, 2021

Copyright $\odot 2021$ Korean Society of Interventional Neuroradiology

This is an Open Access article distributed under the terms of the Creative Commons Attribution Non-Commercial License (http://creativecommons.org/licenses/by-nc/4.0) which permits unrestricted non-commercial use, distribution, and reproduction in any medium, provided the original work is properly cited.

pISSN 2093-9043 eISSN 2233-6273 
also be applied to the Asian population. In addition, available studies on ICAS LVO could be used to guide the necessary course of treatment.

There are lots of factors that contribute to EVT outcomes. Efficacious time management, including times from door to puncture (in-hospital process) and from puncture to reperfusion (EVT procedure), leads to better outcomes. In addition, a fast EVT procedure and complete reperfusion can lead to a reduction in stroke volume, as reflected by diffusion reversal. Diabetes mellitus and contrast media may work as risk factors toward poorer outcomes. On the other hand, to widen the therapeutic indication of EVT, especially for patients with large stroke burden, reperfusion injury should be a concern, and neuroprotection has been revisited in the current EVT era.

The Acute Stroke due to Intracranial Atherosclerotic occlusion and Neurointervention Korean Retrospective (ASIAN KR) registry (January 2011-February 2016) from 3 Korean stroke centers not only provided a general perspective on EVT along with essential cues about ICAS LVO but also analyzed factors contributing to EVT outcomes. ${ }^{1-14}$ The present article is based on the substudies from the ASIAN KR registry and provides a comprehensive review on EVT that would aid physicians in devising specific treatment regimens. In part I, we review EVT outcomes in Asian countries and outcomes in patients with ICAS LVO. In addition, evolving EVT techniques are briefly described. In part II, we review various factors that contribute to EVT outcomes for patients with AIS and LVO. We hope readers can widen their understanding of EVT for the Asian population and associated factors related to its outcomes.

PART I. Outcomes and techniques in EVT for LVO

- Comparable real-world outcomes of EVT

- Comparable ICAS-LVO outcomes

- Evolving EVT devices and techniques

PART II. Factors contributing EVT outcomes

- Onset-to-door vs. in-hospital time

- Diffusion reversal: a goal toward rapid complete reperfusion

- Is diabetes mellitus a risk factor for EVT?

- Contrast-induced acute kidney injury

- Reperfusion injury and neuroprotection study

\section{PART I. OUTCOMES AND TECHNIQUES IN EVT FOR LVO}

\section{Comparable real-world outcomes of EVT}

The past several years have witnessed dynamic developments in the field of EVT with respect to AIS. While 3 RCTs for EVT (IMS-3, MR RESCUE, and SYNTHESIS Expansion studies) failed in 2013, ${ }^{15-17}$ the next EVT trial, MR CLEAN, was successful in 2014. ${ }^{18}$ Besides this trial, other successful trials in 2015, including ESCAPE, SWIFT PRIME, EXTEND IA, and REVASCAT, emphasized the efficacy of EVT when compared with conventional stroke treatment. ${ }^{19-22}$ The success of these studies could be attributed to the development of better imaging protocols for appropriate patient selection, advancements in thrombectomy devices, and reduced time from door to treatment. ${ }^{23}$ The treatment guidelines for AIS were amended by the American Stroke Association, and new guidelines were compiled by the Korean Stroke Society, Korean Society of Interventional Neuroradiology, and Society of Korean Endovascular Neurosurgeons. ${ }^{24,25}$ Although these developments were encouraging, there were specific concerns regarding the extensiveness of the studies. Notably, the successful trials that were performed in Western countries rarely included Asian patients. Clinical trials of therapeutic drugs, such as non-vitamin K antagonist oral anticoagulants, usually involve a substantial proportion of Asian patients. ${ }^{26-29}$ Asian populations have also been included in many clinical trials regarding coronary percutaneous intervention. Moreover, several RCTs from Korea have provided evidence that percutaneous coronary intervention can replace coronary bypass surgery in patients with coronary artery disease. ${ }^{30-32}$

As for studies on the efficacy of EVT for Asian patients with LVO, underlying ICAS has been regarded as a challenging hurdle. Thus, a lack of studies involving Asian subjects necessitates a comprehensive review involving a single-center or multicenter registry. In Table 1, the outcomes from major RCTs and representative Korean registry studies have been documented. ${ }^{1,18-20,33-39}$ Overall, the outcomes of EVT from multicenter registry studies in Korea were comparable to those of major RCTs. Furthermore, good clinical outcomes, defined by a modified Rankin Scale (mRS) of 0-2 at 3 months, were $50-52 \%$ in the anterior circulation, compared to $33 \%$ to $60 \%$ in the major RCTs. ${ }^{1,37,39}$ The data from the ASIAN KR registry revealed that the rates of good clinical outcomes improved after Solitaire FR, Trevo, and the second-generation Penumbra system were approved in Korea.' 
Recently, RCTs, including the BEST and BASICS trials, for LVO in the posterior circulation failed to prove the efficacy of EVT when compared with the best medical treatment. ${ }^{35,36} \mathrm{In}$ the BEST trial, the low rates of good outcomes (33\%) might be due to the relatively low rates of successful reperfusion (71\%). ${ }^{35}$ In the BASICS trial, presented in the European Stoke Organisation and World Stroke Organization (ESO-WSO) 2020 Joint Meeting, the rates of good clinical outcomes as a secondary outcome were also low (35\%), although the information regarding reperfusion rates was absent in the presented material. ${ }^{36} \mathrm{It}$ is suspected that the high prevalence of underlying ICAS in the posterior circulation might affect the outcomes. ${ }^{40,41}$ With respect to EVT techniques and clinical outcomes, it is more challenging for physicians to treat ICAS LVO in the posterior circulation. ${ }^{42}$ It is believed that clinical outcomes would be better in future trials on the posterior circulation occlusion if the EVT strategy is stratified by a predictor of ICAS combined with baseline infarct volume and a time window to groin puncture. ${ }^{2,3}$

After the RCTs for a late time window were successful, ${ }^{33,34}$ new guidelines were reported. ${ }^{43,44}$ Based on the single-center or multicenter registry studies in addition to RCTs, it is rea- sonable to perform EVT for LVOs of the anterior circulation in both early and late time windows and to cautiously try EVT for LVOs of the posterior circulation as per the revised guidelines.

\section{Comparable ICAS-LVO outcomes}

In terms of stroke subtypes according to the trial of ORG 10172 in acute stroke treatment (TOAST) classification, among the general population with AIS, large artery atherosclerosis is relatively more prevalent than cardioembolism in Asian countries, while the opposite is true in western countries. ${ }^{45}$ In addition, compared to extracranial atherosclerosis, intracranial atherosclerosis is more prevalent in Asian patients than in Western patients. ${ }^{45-48}$ With this background, stroke physicians in Asian countries have worried about potential treatment difficulties in MT despite successful reports from Western countries.

Fortunately, the prognosis of ICAS LVO has been reported to be comparable to that of embolic LVO in the anterior circulation. In most cases, ICAS LVO accounted for around 15-20\% of all intracranial LVOs of the anterior circulation, although its definition is a bit varied. ${ }^{4,49}$ The rates of good clin-

Table 1. EVT prognosis of major randomized control trials and Korean multicenter registry studies

\begin{tabular}{|c|c|c|c|c|c|c|c|c|}
\hline Studies & Study period & No. & $\begin{array}{c}\text { Brain } \\
\text { territory }\end{array}$ & $\begin{array}{c}\text { Age } \\
\text { (mean) }\end{array}$ & $\begin{array}{l}\text { Initial NIHSS } \\
\text { (median) }\end{array}$ & $\begin{array}{l}\text { EVT time window } \\
\text { (range or mean) }\end{array}$ & $\begin{array}{l}\mathrm{mTICl} \\
2 \mathrm{~b} / 3\end{array}$ & $\begin{array}{l}\mathrm{mRS} 0-2 \\
\text { at } 3 \mathrm{~m}\end{array}$ \\
\hline \multicolumn{9}{|c|}{ Major randomized control trials } \\
\hline MR CLEAN ${ }^{18}$ & Dec 2010-Mar 2014 & 233 & Anterior & $66^{*}$ & 17 & Up to $6 \mathrm{~h}$ & $59 \%$ & $33 \%$ \\
\hline ESCAPE $^{19}$ & Feb 2013-Oct 2014 & 165 & Anterior & $71^{*}$ & 16 & Up to $12 \mathrm{~h}$ & $72 \%$ & $53 \%$ \\
\hline SWIFT PRIME ${ }^{20}$ & Dec 2012-Nov 2014 & 98 & Anterior & 65 & 17 & Up to $6 \mathrm{~h}$ & $88 \%$ & $60 \%$ \\
\hline DAWN $^{33}$ & Sep 2014-Feb 2017 & 107 & Anterior & 69 & 17 & $6 \mathrm{~h}$ to $24 \mathrm{~h}$ & $84 \%$ & $49 \%$ \\
\hline DEFUSE $3^{34}$ & May 2016-May 2017 & 92 & Anterior & 70 & 16 & $6 \mathrm{~h}$ to $16 \mathrm{~h}$ & $76 \%$ & $45 \%$ \\
\hline $\mathrm{BEST}^{35}$ (failed) & Apr 2015-Sep 2017 & 66 & Posterior & 62 & 32 & Up to $8 \mathrm{~h}$ & $71 \%$ & $33 \%$ \\
\hline BASICS $^{36}$ (failed) & Dec 2011-Dec 2019 & 154 & Posterior & 67 & 21 & Up to $6 \mathrm{~h}$ & - & $35 \%$ \\
\hline \multicolumn{9}{|c|}{ Korean multicenter registry studies } \\
\hline Kim et al. ${ }^{37}$ & Sep 2010-Dec 2015 & 690 & Anterior & 68 & 15 & $234 \mathrm{~min}$ & $80 \%$ & $50 \%$ \\
\hline SECRET ${ }^{38}$ & Jan 2012-Dec 2017 & 500 & Anterior & 70 & 15 & $324 \min$ & $81 \%$ & $52 \%$ \\
\hline ASIAN KR ${ }^{1}$ & Jan 2011 -Feb 2016 & 635 & Anterior & 68 & 16 & $261 \mathrm{~min}$ & $76 \%$ & $52 \%$ \\
\hline Kang et al. ${ }^{39}$ & Jan 2011-Aug 2017 & 212 & Posterior & 71 & 17 & $242 \mathrm{~min}$ & $92 \%$ & $45 \%$ \\
\hline SECRET ${ }^{38}$ & Jan 2012-Dec 2017 & 85 & Posterior & 72 & 15 & $365 \mathrm{~min}$ & $80 \%$ & $45 \%$ \\
\hline ASIAN KR ${ }^{1}$ & Jan 2011-Feb 2016 & 72 & Posterior & 67 & 19 & $298 \min$ & $86 \%$ & $42 \%$ \\
\hline
\end{tabular}

NIHSS, National Institute of Health Stroke Scale.

For the data from the SECRET and ASIAN KR registry studies, outcomes were recalculated in the anterior and posterior circulations, for appropriate comparison to other studies. The data of the SECRET was sent by Dr. Young Dae Kim.

${ }^{*}$ A median value. 
ical outcomes were substantial (over 45\%) after EVT for ICAS LVO. ${ }^{4,49}$ These outcomes were comparable to embolic LVO, in which the rates of good clinical outcomes were $46-55 \%{ }^{4,49}$ Previous studies showed that patients were younger, the initial severity was milder, and baseline infarct volume was smaller, while collaterals were more abundant in ICAS LVO than in embolic LVO. ${ }^{50}$ From these confounding factors, ICAS LVO was shown to be less associated with good outcomes when major confounding factors were adjusted and embolic LVO was referenced. ${ }^{4}$ With respect to ICAS LVO in the posterior circulation, while recent studies reported a substantial portion of good clinical outcomes (46-60\%), ${ }^{51,52}$ previous studies reported worse clinical outcomes in comparison to embolic LVO (11\% vs. 38\%). ${ }^{42}$

In a meta-analysis study regarding ICAS LVO, the successful reperfusion rate was $88 \%$ (95\% confidence interval [Cl], 8492\%), and good clinical outcomes were seen in 52\% (95\% Cl, 47-56\%) of patients. ${ }^{53}$ Another meta-analysis study showed no difference in successful reperfusion rate (odds ratio [OR], 0.67; 95\% Cl, 0.36-1.27) and good clinical outcomes (OR, 1.16; $95 \% \mathrm{Cl}, 0.85-1.58)$ between ICAS and non-ICAS LVOs. ${ }^{54}$ It is believed that the prognosis of ICAS LVO has substantially improved over time and is expected to have a higher rate of good clinical outcomes with methodological advancements and device development for EVT.

\section{Evolving EVT devices and techniques}

Before the RCTs for intracranial LVO were successful, the use of the Merci device or intra-arterial fibrinolytic drug infusion was the mainstay of treatment, but they did not have a sufficient reperfusion rate. ${ }^{15}$ Presently, it is a base using current standard thrombectomy devices such as stent retrievers and contact-aspiration catheters, which had improved reperfusion grade, thereby rendering the RCTs successful. ${ }^{55-58}$ In addition, evidence shows that the use of a balloon guide catheter improved the rate of complete reperfusion and good clinical outcomes with either stent retrievers or contact aspiration devices. ${ }^{59-62} \mathrm{~A}$ new occlusion in the Willisian collateral supply, which often occurs during the MT procedure, was associated with grave outcomes. ${ }^{5}$ The use of a balloon catheter may help to prevent new embolization during the procedure. ${ }^{63}$ For overcoming a tortuous cervical vessel, intermediate or distal delivery catheters might be useful tools. ${ }^{64}$ Also, for challenging supra-aortic access, a modified use of a balloon guide catheter can be helpful. ${ }^{64}$ While removing a fibrin clot in a bifurcation, which is well known to be resistant to stent retrieval, ${ }^{65}$ a double stent-retriever technique has been tried, although safety issues should be considered accordingly. ${ }^{66,67}$

Concomitantly, the MT methods against ICAS LVO have been the first-line in the absence of a standardized method to differentiate ICAS and embolic occlusion on the basis of baseline angiography. Stent retrievers, such as Solitaire, have been shown to be effective and safe for ICAS LVO.,68 Contact aspiration techniques have also been shown to be feasible, although miscontact or dissection risks have been reported. ${ }^{7,69,70}$ The next step for remnant stenosis following mechanical thrombectomy could include antiplatelet agent infusion and angioplasty with or without intracranial stenting. Because in situ thrombosis is the main mechanism in ICAS LVO, ${ }^{40}$ stabilization with local antiplatelet infusion is reasonable. In an earlier study, the local infusion of abciximab, an antiplatelet agent, was reported to be effective in preventing reocclusion in a specific case series. ${ }^{71,72} \mathrm{How}$ ever, abciximab potentially has a bleeding risk due to its irreversible action. As such, tirofiban, a reversible antiplatelet agent, has been more frequently applied in EVT situations. Until now, tirofiban intra-arterial (IA) treatment has been reported to be effective in stabilizing remnant stenosis and preventing reocclusion in several cases. ${ }^{8,73,74}$ In the context of blood-brain barrier breakdown, additional antiplatelet infusion has been considered for intracerebral hemorrhage (ICH) development. However, IA tirofiban infusion has a protective effect to prevent $\mathrm{ICH}$ that results from a reduction in the final infarct volume. ${ }^{8}$ Intracranial stenting has also been extensively reported with studies showing its feasibility against ICAS LVO.75,76 Although it is a powerful recanalization method, stenting requires antiplatelet pretreatment for successful long-term deployment, and the density of post-EVT strong antiplatelet administration may induce symptomatic $\mathrm{ICH}$, especially in patients with IV thrombolysis. Lastly, recent studies have shown that stenting improves clinical outcomes compared with management without stenting in patients with failed MT with or without underlying ICAS. ${ }^{77-79}$ However, this result should not be generalized to ICAS LVO because failed MT does not always indicate underlying ICAS. ${ }^{9,78}$ On the other hand, emergent stenting for extracranial atherosclerotic lesions on ICA has been reported in several studies, which showed its efficacy and safety. ${ }^{80-82}$ However, extracranial stenting for tandem occlusions resulted in frequent postEVT ICH, thereby making antithrombotic treatment for stroke prevention difficult. ${ }^{10}$ If antithrombotic treatment cannot 
be applied due to hemorrhages, a recurrence of stroke or reocclusion of recanalized vessels would increase in clinical practice. The decision for deployment of foreign material in the vessel should be cautious.

\section{PART II. FACTORS CONTRIBUTING TO EVT OUTCOMES}

\section{Onset-to-door vs. in-hospital time}

While it is often considered that time is brain, ${ }^{83}$ it might seem strange that onset-to-door time is no longer considered a prognostic factor. ${ }^{1,84}$ This discrepancy is attributable to patient selection for EVT among patients with highly-varied collateral grades. Patients with poor collaterals could be denied EVT if rapid infarct growth or poor clinical outcomes are predicted. ${ }^{85-88}$ In addition, recent RCTs studied the effect of an elongated treatment time window for good clinical outcomes. ${ }^{33,34}$ If door-to-randomization time is assumed to be short, the time from last normal to door was around 10 to 12 hours, but patients who underwent EVT showed $44 \%$ to $49 \%$ of good clinical outcomes in the late-window trials. ${ }^{33,34}$ Despite the inconsistency between onset-to-door time and prognosis, all systematic efforts should be continued for a patient with emergent LVO to reach a thrombectomy center. ${ }^{89}$ In real practice, many patients could not undergo EVT because they arrived late at centers and lost an opportunity for EVT. The number of these patients is substantial, but they are underestimated in most studies.

It is believed that patients with ICAS LVO could be treated in this late time window. Pre-existing stenosis develops abundant collaterals, and a smaller stroke volume could be maintained in such cases. From the ASIAN KR registry study, it was evident that the probability of good clinical outcomes was well maintained for up to 24 hours in the ICAS LVO group, whereas the probability continuously decreased in the embolic LVO group. ${ }^{4}$ In a recent study, the prognosis of EVT was acceptable (39\% of good outcomes at 3 months) even beyond 24 hours after stroke onset, and patients with ICAS LVO were the most predominant (46\%), followed by those with tandem occlusion (33\%) and cardioembolism (21\%). ${ }^{90}$ There is an increasing need to perform clinical trials for the treatment of ICAS LVO in the near future.

Based upon appropriate patient selection, in-hospital time is the main prognostic factor. From the ASIAN KR registry, short door-to-puncture time and short procedure time were found to be independently associated with good clinical outcomes in multivariable analyses. . Among RCTs, the ESCAPE trial only showed a significant decrease in mortality. ${ }^{19}$ This trial had strict criteria for in-hospital pre-EVT time. The image-to-puncture time of over 1 hour was considered as an exclusion criterion. ${ }^{91}$ On this ground, a short door-topuncture time is the responsibility of each thrombectomy center, and all efforts should be focused on a reduction of the time. . $^{92-94}$

\section{Diffusion reversal: a goal toward rapid complete reperfusion}

Diffusion reversal was observed in a portion of patients with acute ischemic stroke and EVT, as evident from the evaluation of pretreatment and post-treatment magnetic resonance imaging (MRI) scans from the ASIAN KR registry. When the diffusion volume was subjected to a blinded evaluation, 63 (15.5\%) of 404 patients showed a decrease in volume. ${ }^{11}$ The diffusion reversal was independently associated with good clinical outcomes $(\mathrm{OR}, 2.5 ; 95 \% \mathrm{Cl}, 1.1-5.9)$. $^{11}$ Among various factors, complete reperfusion (modified treatment in cerebral ischemia [ $\mathrm{mTICl}$ 3) and short time from imaging to reperfusion were proven to be associated with diffusion reversal on multivariable analysis. ${ }^{11}$ A change of diffusion-weighted MRI due to a reduction of the apparent diffusion coefficient (ADC) of water is known to represent early cytotoxic edema owing to a failure in cellular energy. ${ }^{95}$ An animal study in which cerebral ischemia was induced showed that ATP and glucose were depleted and severe lactic acidosis was sustained in animals without any recovery in the values of $A D C^{96}$ In contrast, the result of diffusion reversal suggested that brain tissue can also be salvaged with EVT. Indeed, an early study showed that ATP and glucose are replenished to near normal range, and lactic acidosis is substantially reversed in animals with a recovery in the ADC values. $^{96}$

In the clinical setting, however, physicians should be cautious about diffusion volume. Diffusion volume can be variously calculated according to each threshold of the ADC value. ${ }^{97}$ If the diffusion volume is strictly defined with a very low ADC threshold, diffusion reversal might happen less because of the initial smaller volume. Infarct volume by manual evaluation on the diffusion-weighted imaging (DWI) map was twice that of the threshold ADC value at $600 \times 10^{-6} \mathrm{~mm}^{2} / \mathrm{s}^{97}$ Although a wide variation of diffusion reversal rate has been reported in the clinical settings, the frequency appears to 
increase in EVT when compared with intravenous (IV) thrombolysis. $^{98}$

The results of diffusion reversal indicate that the goal of EVT should be the achievement of a first-pass effect (FPE) and complete reperfusion ( $\mathrm{mTICl} 2 \mathrm{c} / 3$ ) rather than successful reperfusion ( $\mathrm{mTICl} 2 \mathrm{~b} / 3$ ). Recent reports regarding FPE and $\mathrm{mTICI} 2 \mathrm{c} / 3$ are in line with the results of diffusion reversal, which suggest technical and device improvement. ${ }^{99-104}$ It is believed that all the efforts of stroke physicians and neurointerventionists with all the best and evolving devices would shorten the image to reperfusion time and increase the complete reperfusion rate.

\section{Is diabetes mellitus a risk factor for EVT?}

Diabetes mellitus is not only a risk factor for the occurrence of acute ischemic stroke and the development of atherosclerosis but also a prognostic factor of acute ischemic stroke and a predictor of early neurological deterioration. ${ }^{105-108}$ Whereas occurrence issues are a preventive concern, prognostic issues are an emergent treatment concern. For IV thrombolytic treatment, a combination of the history of stroke and diabetes used to be a contraindication on the European label. ${ }^{109}$ While most contraindications focus on the risk of $\mathrm{ICH}$ following thrombolytic treatment, the combined risk factors were based on a less-favorable benefit/risk ratio. ${ }^{110}$ In reality, the combined risk factors were not associated with an increase of symptomatic $\mathrm{ICH}$ among patients with IV thrombolysis within a 3-4.5 hours window as observed in the data from the Get With The Guidelines-Stroke Registry. ${ }^{111}$ Nevertheless, diabetes mellitus (DM) is a risk factor for $\mathrm{ICH}$ in patients with acute ischemic stroke who undertook IV or intra-arterial thrombolysis. ${ }^{112-114}$ In the PROACT II study, which was a successful RCT for EVT, 113 the frequency of symptomatic $\mathrm{ICH}$ was higher in the thrombolysis group than in the control group, and the prognosis was worse in patients with symptomatic $\mathrm{ICH} .{ }^{114}$ Blood glucose level $>200 \mathrm{mg} / \mathrm{dL}$ was the only factor associated with symptomatic ICH in the study. ${ }^{114}$

It is well known from animal studies that DM or hyperglycemia is associated with the rapid growth of cerebral infarction and increased chances of hemorrhagic transformation even without thrombolysis, mediated by perfusion deficit and free radicals. ${ }^{115,116}$ The animal models had undergone
NonDM 0.5 h tMCAO (24 h)

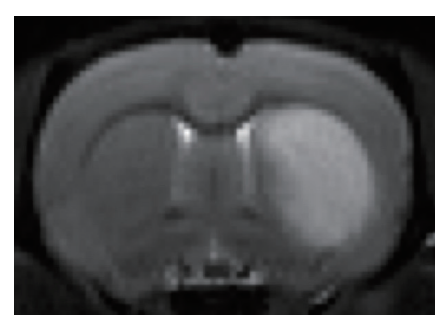

NonDM 2 h tMCAO (24 h)

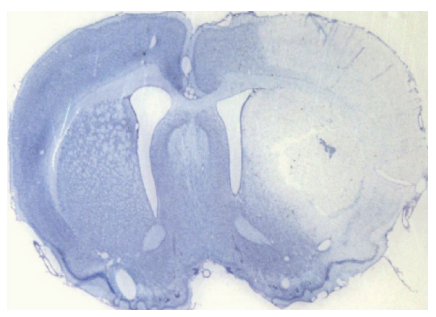

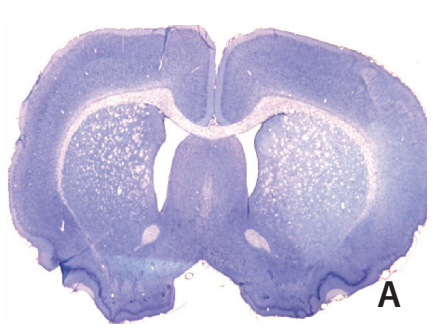

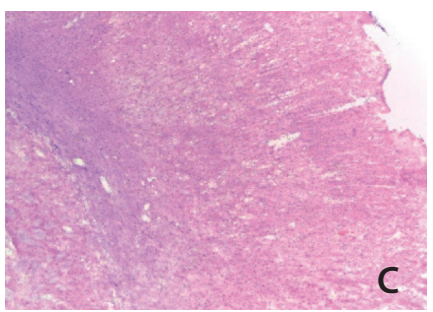

DM 0.5 h tMCAO (24 h)
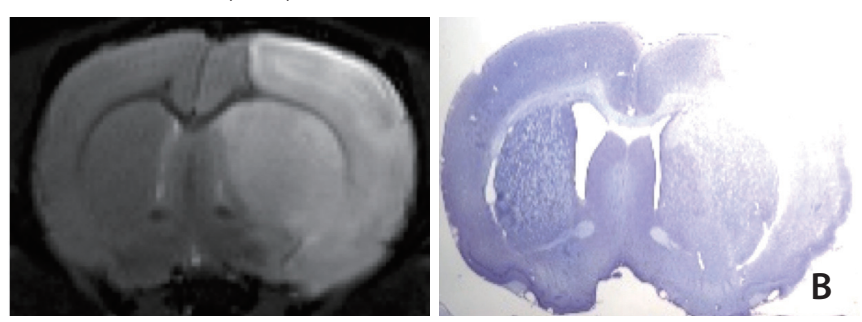

DM 2 h tMCAO (8 h)
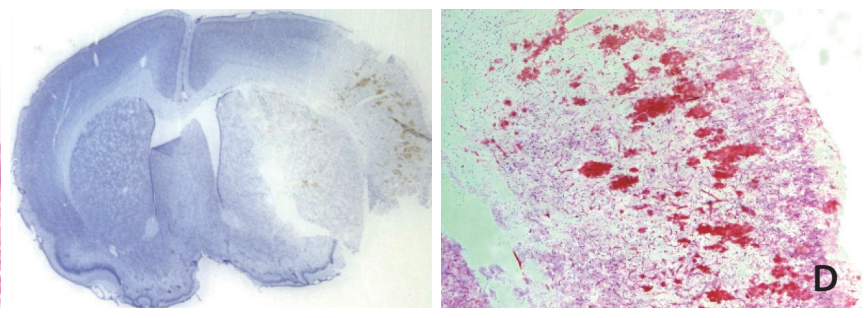

Fig. 1. Representative images of infarct volume and hemorrhagic transformation among rat models with cerebral ischemia in the presence or absence of diabetes mellitus (DM) induction. (A, B) Models of 30-minute ischemia and reperfusion in the unilateral middle cerebral artery with a thread ( 0.5 hours transient middle cerebral artery occlusion [tMCAO], sacrificed 24 hours after reperfusion); T2-weighted imaging by $9.4 T$ magnetic resonance imaging taken in the Institute for Basic Science (Suwon, Korea) (left) and cresyl violet staining (right). (A) In a non-DM rat, the cerebral infarction is relatively small. (B) In a DM rat, the infarction is evident on the entire middle cerebral artery (MCA) territory induced only by 30 -minute ischemia. (C, D) Models of 2 hours ischemia and reperfusion in the MCA ( 2 hours tMCAO, sacrificed 24 and 8 hours after reperfusion in non-DM and DM rats, respectively); cresyl violet (left) and hematoxylin and eosin staining (right). (C) The evident territorial infarction is induced by 2 hours tMCAO, the most common rodent model of cerebral ischemia, in a non-DM rat. (D) The territorial infarction is evident in the early time point, and prominent hemorrhagic transformation is shown in a DM rat with 2 hours tMCAO. The serum HbA1c was around 10-11\%, 4 weeks after intraperitoneal streptozotocin injection in the DM rats. Materials are from the corresponding author's own laboratory (JSL; Suwon, Korea). Low magnification, X6.7. High magnification, $\times 400$. 
transient occlusion and reperfusion procedures, which highly correspond to patients with LVO and reperfusion by MT. Representative features of the resultant infarct volume and hemorrhagic transformation from animal models are shown in Fig. 1A-D.

In the modern thrombectomy era, DM or high admission glucose levels were shown to affect the prognosis and the occurrence of $\mathrm{ICH}{ }^{12}$ Overall, a moderate to high admission glucose level (>110 mg/dL) was associated with a lower rate of good clinical outcomes after EVT, and overt hyperglycemia (>170 mg/dL), which was closely related to the history of DM, also was significantly associated with a higher rate of the occurrence of parenchymal hematoma. ${ }^{12}$ Similarly, these associations were reported in a previous RCT, MR CLEAN. ${ }^{117}$ When the authors defined admission hyperglycemia as $>7.8$ $\mathrm{mmol} / \mathrm{L}(141 \mathrm{mg} / \mathrm{dL})$ and impaired fasting glucose as $>5.5$ $\mathrm{mmol} / \mathrm{L}(99 \mathrm{mg} / \mathrm{dL})$, those factors were associated with a higher symptomatic $\mathrm{ICH}$ and a lower rate of good clinical outcomes, respectively. ${ }^{117}$

From point of view of mechanisms, the distinction between normal, moderate, and overt hyperglycemia is reasonable (Fig. 2). Moderate hyperglycemia did not directly affect the occurrence of parenchymal hematoma but negatively affected prognosis in the ASIAN KR study. Worse prognosis in hyperglycemic or diabetes patients might be related to poor collaterals in the hyperglycemic environment, resulting in infarct volume growth. ${ }^{118} \mathrm{~A}$ higher rate of $\mathrm{ICH}$ might be related to higher levels of free radicals and advanced glycation products in a sustained very high glucose exposure in the circulation systems or enlarged infarct volume itself, in which blood-brain barriers are vulnerable. ${ }^{118}$

Despite the worse prognosis, EVT for patients with moderate to overt hyperglycemia or DM should not be discouraged. In the above registry study, the ratio of good clinical

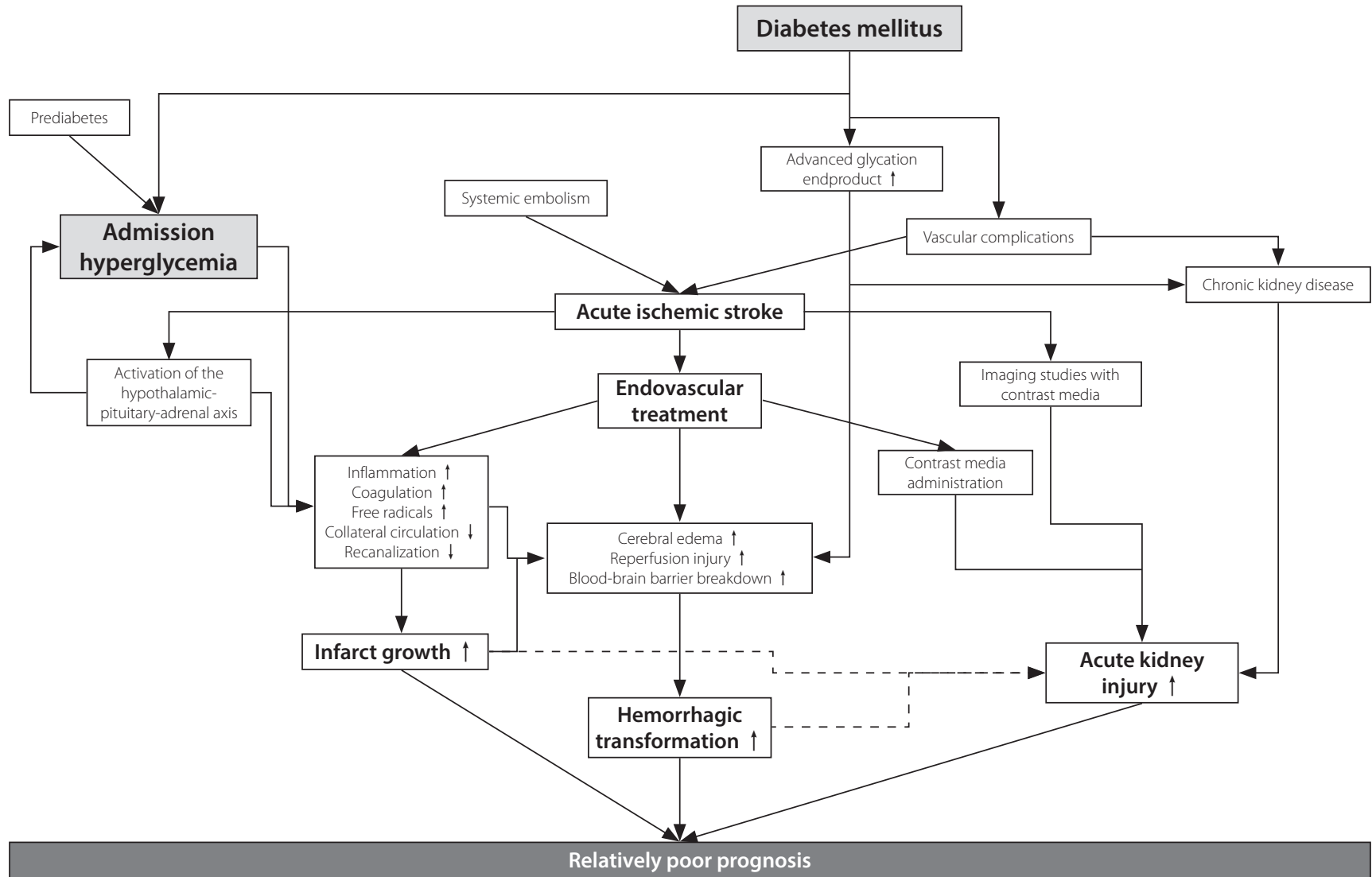

Fig. 2. The possible pathomechanism of poor prognosis in patients with diabetes mellitus or admission hyperglycemia who have acute ischemic stroke and endovascular treatment. Although there are overlapped features among the representative complications, including infarct growth, hemorrhagic transformation, and acute kidney injury, the main contributing factors seem to be somewhat distinctive. Infarct growth may be attributable to admission hyperglycemia especially upon recanalization failure. Although hemorrhagic transformation and acute kidney injury share a common factor, diabetes mellitus, different factors seem to respectively affect each complication. Hemorrhagic transformation more likely occurs after reperfusion injury. Severe stroke might indirectly affect the occurrence of acute kidney injury (dashed line). 
Table 2. Nephropathic complications in various clinical situations

\begin{tabular}{|c|c|c|c|c|c|c|c|}
\hline Studies & Study period & No. & Definition & $\begin{array}{c}\text { Contrast } \\
\text { media }\end{array}$ & Main risk factors & AKI/ARF & $\begin{array}{c}\text { Dialysis/ } \\
\text { replacement }\end{array}$ \\
\hline \multicolumn{8}{|c|}{ Cervicocerebral contrast CT protocol } \\
\hline $\begin{array}{l}\text { Josephson et } \\
\text { al. }^{120}\end{array}$ & $\begin{array}{l}\text { Apr 2000- } \\
\text { Oct } 2004\end{array}$ & $\begin{array}{c}1,075 \\
\text { (no disease } \\
\text { information) }\end{array}$ & $\begin{array}{c}\text { A rise in serum } \\
\text { creatinine }>0.5 \\
\text { mg/dL within } 1 \\
\text { week }\end{array}$ & $\begin{array}{l}150 \mathrm{~mL} \text { of } \\
\text { IV iohexol } \\
\text { (CTA+CTP) }\end{array}$ & NA & $4.8 \%$ & $0.2 \%$ \\
\hline Krol et al. ${ }^{121}$ & $\begin{array}{l}\text { Apr 2002- } \\
\text { Apr } 2005\end{array}$ & $\begin{array}{l}481 \text { (with an } \\
\text { acute stroke } \\
\text { syndrome) }\end{array}$ & $\begin{array}{l}\text { A rise in serum } \\
\text { creatinine }>25 \% \\
\text { within } 5 \text { days }\end{array}$ & $\begin{array}{c}\text { loversol } \\
\text { (mostly for CT } \\
\text { angiography) }\end{array}$ & NA & $3 \%$ & $0 \%$ \\
\hline Hopyan et al. ${ }^{122}$ & $\begin{array}{l}\text { Jan 2003- } \\
\text { Aug } 2007\end{array}$ & $\begin{array}{c}198 \\
\text { (suspected } \\
\text { acute stroke) }\end{array}$ & $\begin{array}{l}\text { A rise in serum } \\
\text { creatinine }>25 \% \\
\text { within } 3 \text { days }\end{array}$ & $\begin{array}{l}\text { lodixanol, } \\
\text { iohexol } \\
\text { (mostly for } \\
\text { CTA } \pm \text { CTP) }\end{array}$ & NA & $2.9 \%$ & $0 \%$ \\
\hline
\end{tabular}

\begin{tabular}{|c|c|c|c|c|c|c|c|}
\hline \multicolumn{8}{|c|}{ Cervicocerebral and spinal digital subtraction angiography } \\
\hline Prasad et al. ${ }^{123}$ & $\begin{array}{c}\text { Jan } 2011- \\
\text { Feb } 2013\end{array}$ & $\begin{array}{c}158 \text { (no } \\
\text { definite renal } \\
\text { disease) }\end{array}$ & $\begin{array}{l}\text { A rise in serum } \\
\text { creatinine }>0.3 \\
\mathrm{mg} / \mathrm{dL} \text { or }>50 \% \\
\text { within } 48 \mathrm{~h}\end{array}$ & lohexol & $\begin{array}{l}\text { DM plus high- } \\
\text { dose contrast }\end{array}$ & $2.5 \%$ & $0 \%$ \\
\hline \multicolumn{8}{|c|}{ Overall acute stroke } \\
\hline Covic et al. ${ }^{124}$ & $\begin{array}{l}\text { Jan 2005- } \\
\text { Jan } 2006\end{array}$ & $\begin{array}{l}1,090 \\
\text { (hemorrhagic } \\
\text { stroke in } \\
14.5 \%)\end{array}$ & $\begin{array}{l}\text { Any rise in serum } \\
\text { creatinine value } \\
\text { or fall in GFR }\end{array}$ & $\begin{array}{l}\text { lodixanol } \\
\text { (contrast } \\
\text { only used in } \\
\text { necessary } \\
\text { cases) }\end{array}$ & $\begin{array}{l}\text { Old age, low GFR, } \\
\text { CHF, hemorrhagic } \\
\text { stroke }\end{array}$ & $14.5 \%$ & $\begin{array}{l}1 \% \text { (F group } \\
\text { of RIFLE } \\
\text { classification) }\end{array}$ \\
\hline $\begin{array}{l}\text { Tsagalis et } \\
\text { al. }^{125,126}\end{array}$ & $\begin{array}{l}\text { Jan 1993- } \\
\text { Dec } 2007\end{array}$ & 2,155 & $\begin{array}{l}\text { A rise in serum } \\
\text { creatinine }>0.3 \\
\text { mg/dL or }>50 \% \\
\quad \text { within } 48 \mathrm{~h}\end{array}$ & NA & $\begin{array}{c}\text { Baseline stroke } \\
\text { severity \& GFR }\end{array}$ & $27 \%$ & NA \\
\hline Rowe et al. ${ }^{127}$ & $\begin{array}{l}\text { Jun } 2012- \\
\text { Jan } 2016\end{array}$ & $\begin{array}{l}209 \text { (ischemic } \\
\text { stroke only) }\end{array}$ & $\begin{array}{c}\text { A rise in serum } \\
\text { creatinine }>0.5 \\
\mathrm{mg} / \mathrm{dL} \text { or }>25 \% \\
\text { within } 72 \mathrm{~h} \text { of } \\
\text { CTA }\end{array}$ & NA & DM & $14.8 \%$ & NA \\
\hline \multicolumn{8}{|c|}{ Percutaneous coronary interventions } \\
\hline $\begin{array}{l}\text { McCullough et } \\
\text { al. }^{128}\end{array}$ & $\begin{array}{l}\text { Dec 1993- } \\
\text { Aug } 1994\end{array}$ & 1,869 & $\begin{array}{l}\text { A rise in serum } \\
\text { creatinine }>25 \% \\
\text { within } 5 \text { days }\end{array}$ & $\begin{array}{c}\text { Diatrizoate } \\
(55 \%), \\
\text { ioxaglate } \\
\text { meglumine } \\
\text { (33\%), both } \\
(12 \%)\end{array}$ & $\begin{array}{l}\text { Baseline } \mathrm{CrCl}, \mathrm{DM} \text {, } \\
\text { contrast dose }\end{array}$ & $14.5 \%$ & $0.8 \%$ \\
\hline Rihal et al. ${ }^{129}$ & $\begin{array}{l}\text { Jan } 1996- \\
\text { May } 2000\end{array}$ & 7,586 & $\begin{array}{l}\text { A rise in serum } \\
\text { creatinine } \\
>0.5 \mathrm{mg} / \mathrm{dL} \\
\text { within } 48 \mathrm{~h}\end{array}$ & lopamidol & $\begin{array}{c}\text { Baseline } \mathrm{Cr}>2.0 \text {, } \\
\text { DM with } \mathrm{Cr}<2.0, \\
\text { old age, } \mathrm{CHF} \\
\text { contrast volume }\end{array}$ & $3.3 \%$ & $0.3 \%$ \\
\hline Gruberg et al. ${ }^{130}$ & $\begin{array}{l}\text { NA } \\
\text { (published in } \\
\text { 2000) }\end{array}$ & $\begin{array}{c}439 \text { (baseline } \\
\text { Cr }>1.8)\end{array}$ & $\begin{array}{l}\text { A rise in serum } \\
\text { creatinine }>25 \% \\
\text { within } 48 \mathrm{~h}\end{array}$ & $\begin{array}{l}\text { loxaglate } \\
\text { meglumine }\end{array}$ & $\begin{array}{l}\text { Blood transfusion, } \\
\text { low ejection } \\
\text { fraction, contrast } \\
\text { volume }\end{array}$ & $37 \%$ & $7 \%$ \\
\hline Marenzi et al. ${ }^{131}$ & $\begin{array}{l}\text { Jan 2002- } \\
\text { Sep } 2007\end{array}$ & 561 (STEMI) & $\begin{array}{c}\text { A rise in serum } \\
\text { creatinine }>25 \% \\
\text { within } 72 \mathrm{~h}\end{array}$ & $\begin{array}{l}\text { lomeprol or } \\
\text { iohexol }\end{array}$ & Contrast volume & $20.5 \%$ & $2.5 \%$ \\
\hline
\end{tabular}


Table 2. Continued

\begin{tabular}{|c|c|c|c|c|c|c|c|}
\hline Studies & Study period & No. & Definition & $\begin{array}{l}\text { Contrast } \\
\text { media }\end{array}$ & Main risk factors & AKI/ARF & $\begin{array}{c}\text { Dialysis/ } \\
\text { replacement }\end{array}$ \\
\hline \multicolumn{8}{|c|}{ Endovascular treatment for acute ischemic stroke } \\
\hline Loh et al. ${ }^{132}$ & $\begin{array}{l}\text { Sep 2002- } \\
\text { Jan } 2008\end{array}$ & 99 & $\begin{array}{l}\text { A rise in serum } \\
\text { creatinine }>0.3 \\
\text { mg/dL or }>50 \% \\
\text { within } 48 \mathrm{~h}\end{array}$ & lohexol & No adjusted data & $3 \%$ & $0 \%$ \\
\hline Sharma et al. ${ }^{133}$ & $\begin{array}{c}\text { Jan 2006- } \\
\text { Jan } 2011\end{array}$ & 194 & $\begin{array}{l}\text { A rise in serum } \\
\text { creatinine }>0.3 \\
\mathrm{mg} / \mathrm{dL} \text { or }>50 \% \\
\text { within } 48 \mathrm{~h}\end{array}$ & loversol & No adjusted data & $1.5 \%$ & $0 \%$ \\
\hline Diprose et al. ${ }^{134}$ & $\begin{array}{l}\text { Mar } 2011- \\
\text { Mar } 2019\end{array}$ & 333 & $\begin{array}{l}\text { A rise in serum } \\
\text { creatinine }>0.3 \\
\mathrm{mg} / \mathrm{dL} \text { or }>50 \% \\
\text { at } 24-72 \mathrm{~h}\end{array}$ & lohexol & Low GFR, DM & $3.3 \%$ & $0 \%$ \\
\hline Jia et al. ${ }^{135}$ & $\begin{array}{l}\text { Sep 2016- } \\
\text { Sep } 2017\end{array}$ & $\begin{array}{l}94 \text { with } \\
\text { CTA+EVT } \\
\text { (87 in CTA } \\
\text { group) }\end{array}$ & $\begin{array}{l}\text { A rise in serum } \\
\text { creatinine }>25 \% \\
\text { within } 48 \text { h of } \\
\text { CTA }\end{array}$ & lodixanol & NA & $\begin{array}{c}7.4 \% \\
(2.3 \% \\
\text { in CTA } \\
\text { group, } \\
\mathrm{P}=0.172)\end{array}$ & \\
\hline ASIAN KR ${ }^{13}$ & $\begin{array}{c}\text { Jan } 2011- \\
\text { Feb } 2016\end{array}$ & 601 & $\begin{array}{c}\text { A rise in serum } \\
\text { creatinine }>0.3 \\
\text { mg/dL within } 48 \\
\text { h or }>50 \% \text { within } \\
7 \text { days }\end{array}$ & $\begin{array}{l}\text { lodixanol, } \\
\text { lopamidol }\end{array}$ & $\begin{array}{l}\text { DM, contrast } \\
\text { dose, } \\
\text { unsuccessful } \\
\text { reperfusion }\end{array}$ & $9.8 \%$ & $0.8 \%$ \\
\hline
\end{tabular}

AKI, acute kidney injury; ARF, acute renal failure; CT, computed tomography; IV, intravenous; CTA, computed tomographic angiography; CTP, computed tomographic perfusion; NA, not available; DM, diabetes mellitus; GFR, glomerular filtration rate; CHF, congestive heart failure; RIFLE, Risk, Injury, Failure, Loss, and End-stage Kidney; CrCl, creatinine clearance; Cr, creatinine; STEMI, ST-elevation myocardial infarction; EVT, endovascular treatment; ASIAN KR, Acute Stroke due to Intracranial Atherosclerotic occlusion and Neurointervention Korean Retrospective.

outcomes was over $50 \%$ in the moderate and overt hyperglycemia groups, respectively, whereas it was over $75 \%$ in the normal group. ${ }^{12}$ EVT would be helpful in patients with hyperglycemia or DM if the EVT is meticulously decided. Nevertheless, stroke physicians and neurointerventionists should recognize these complications when they decide EVT and should warn about the same to the concerned patients and caregivers. Intensive glucose control using insulin did not improve clinical outcomes once stroke occurred; rather, it induced severe hypoglycemia and other adverse events in the SHINE trial.119 Therefore, further studies should focus on neuroprotection from DM or hyperglycemia besides glucose control.

\section{Contrast-induced acute kidney injury}

The manifestation of acute kidney injury (AKI) after EVT was not rare (around 10\%), but the occurrence of renal replacement therapy was rare $(<1 \%)$ in patients with EVT as per the
ASIAN KR registry. ${ }^{13}$ In a multivariable analysis, however, the occurrence of AKI was independently associated with poor clinical outcomes (modified Rankin Scale 3-6 at 3 months: $\mathrm{OR}, 5 ; 95 \% \mathrm{Cl}, 2-14)$ and with a high mortality rate (OR, 8; 95\% $\mathrm{Cl}, 4-17){ }^{13}$ This AKI is generally associated with the use of iodinated contrast media and typically occurs 48-72 hours after the administration of contrast media in patients with an advanced imaging protocol, percutaneous coronary intervention (PCI), and stroke with or without EVT (Table 2). 13,120-135 A substantial dose of contrast media is not only exposed during neurointervention but also administered for baseline angiography and perfusion imaging, especially for EVT candidates with AIS and LVO. These multiple exposures may increase the risk of AKI in patients with AIS and EVT.

These risk factors and poor clinical outcomes associated with EVT for AIS are similar to those in $\mathrm{PCI}$. In an early PCI study, acute renal failure (ARF) occurred in around $14 \%$ of the 1,869 patients with $\mathrm{PCl}$, among which dialysis was needed 
in less than $1 \% .{ }^{128}$ However, high in-hospital mortality and poor long-term survival were especially associated with the cases of ARF that required dialysis. ${ }^{128}$ The risk factors of ARF occurrence included diabetes mellitus and contrast dose, as well as baseline renal function estimated from creatinine clearance. ${ }^{128,136,137}$ Besides the above risk factors, dehydration, congestive heart failure, and old age are known to be associated with contrast-induced nephropathy $(\mathrm{CIN}){ }^{138}$ To reduce the chance of CIN after EVT, adequate hydration is necessary in patients without congestive heart failure. ${ }^{138}$ In addition, a less nephrotoxic contrast agent should be selected. ${ }^{138}$ In 2006, the US Food and Drug Administration (FDA) database reported iopamidol and iodixanol to be the lowest and iohexol to be the highest toxic agents associated with $\mathrm{CIN}^{139}$ Furthermore, meta-analysis studies have supported that iodixanol or other low-osmolar contrast media, except iohexol, might be good choices for interventional treatment. ${ }^{140,141}$ In the results from the ASIAN KR registry study, the use of iodix- anol accounted for around $72 \%$ of the included patients and iopamidol for $28 \% .^{13}$ Nevertheless, AKI after EVT is not induced only by contrast media. A severe stroke type, hemorrhagic stroke, which does not require much contrast media for brain evaluations, was independently associated with AKI in a study including both ischemic and hemorrhagic stroke patients. ${ }^{124}$

Again, it is imperative to focus on patients with diabetes (Fig. 2). Patients who have baseline diabetic nephropathy would be the most vulnerable to the manifestation of CIN. ${ }^{138,142,143}$ Diabetic patients without nephropathy are also classified into the high-risk group. ${ }^{144}$ On this ground, sufficient warning to patients and their caregivers and appropriate hydration alongside emergent stroke treatment should be given. Although sufficient hydration and minimal use of contrast, and high-dose atorvastatin are suggested to prevent CIN in patients who undergo contrast imaging or endovascular procedures, ${ }^{145,146}$ further studies are warranted

Table 3. Enrolled populations and outcomes in representative studies for neuroprotective treatment

\begin{tabular}{|c|c|c|c|c|c|c|}
\hline Studies & Treatment & Study design & Enrolled population & Endpoint & Outcomes & Comments \\
\hline SAINT $\|^{148}$ & NXY-059 & RCT, phase III & Overall AIS & $\mathrm{mRS}$ & Ineffective & $\begin{array}{l}\text { Reperfusion not considered. } \\
\text { A wide range of severity. }\end{array}$ \\
\hline ESCAPE-NA $1^{149}$ & Nerinetide (NA1) & RCT, phase III & LVO and EVT & $\mathrm{mRS}$ & Insignificant & $\begin{array}{l}\text { ASPECTS criteria: } 5-10 \text {. } \\
\text { Overall high rate of good } \\
\text { outcomes upon modern } \\
\text { EVT. }\end{array}$ \\
\hline SONIC ${ }^{150}$ & Neu2000 & RCT, phase II & LVO and EVT & $\mathrm{mRS}$ & $\begin{array}{l}\text { Enrollment } \\
\text { finished }\end{array}$ & $\begin{array}{l}\text { ASPECTS criteria: 6-10. } \\
\text { Treatment upon modern } \\
\text { EVT. }\end{array}$ \\
\hline ICTuS-2 $2^{151}$ & $\operatorname{TTM}\left(33.0^{\circ} \mathrm{C}\right.$ for $\left.24 \mathrm{~h}\right)$ & RCT, phase $\|/ I\|$ & $\begin{array}{c}\text { Overall AIS and IV } \\
\text { rtPA }\end{array}$ & $\mathrm{mRS}$ & Ineffective & $\begin{array}{l}\text { Reperfusion not considered. } \\
\text { A wide range of severity. }\end{array}$ \\
\hline $\begin{array}{l}\text { Neugebauer et } \\
\text { al. }^{152}\end{array}$ & $\begin{array}{l}\text { TTM }\left(33.0^{\circ} \mathrm{C} \text { for } 72\right. \\
\text { h)+hemicraniectomy }\end{array}$ & $\mathrm{RCT}$ & $\begin{array}{l}\text { Unilateral MCA } \\
\text { infarction with early } \\
\text { hemicraniectomy } \\
\text { within } 48 \mathrm{~h} \text { from } \\
\text { symptom onset }\end{array}$ & Mortality & Ineffective & $\begin{array}{l}\text { Malignant stroke } \\
\text { profile ( }>2 / 3 \text { of MCA } \\
\text { territory+basal ganglia). } \\
\text { Early termination due to } \\
\text { safety concern. }\end{array}$ \\
\hline HARIS $^{153}$ & $\operatorname{TTM}\left(34.5^{\circ} \mathrm{C}\right.$ for $\left.48 \mathrm{~h}\right)$ & $\begin{array}{l}\text { Retrospective, } \\
\text { case-control }\end{array}$ & $\begin{array}{c}\text { Reperfused LVO } \\
\text { (mTICI 2b-3) by EVT } \\
\text { within } 6 \mathrm{~h}\end{array}$ & $\begin{array}{l}\mathrm{mRS}, \mathrm{CT} \\
\mathrm{MRI}\end{array}$ & $\begin{array}{c}\text { More } \\
\text { favorable }\end{array}$ & $\begin{array}{l}\text { Moderate to severe stroke } \\
\text { severity (median ASPECTS } \\
\text { 6). } \\
\text { Treatment upon modern } \\
\text { EVT. }\end{array}$ \\
\hline ASIAN KR ${ }^{14}$ & $\operatorname{TTM}\left(34.5^{\circ} \mathrm{C}\right.$ for $\left.48 \mathrm{~h}\right)$ & $\begin{array}{l}\text { Retrospective } \\
\text { case-control }\end{array}$ & LVO and EVT & $\mathrm{mRS}$ & $\begin{array}{l}\text { More } \\
\text { favorable in } \\
\text { the malignant } \\
\text { trait subgroup }\end{array}$ & $\begin{array}{l}\text { Malignant trait subgroup } \\
\text { (ASPECTS }<6 \text { ). } \\
\text { Treatment upon modern } \\
\text { EVT. }\end{array}$ \\
\hline
\end{tabular}

RCT, randomized control trial; AIS, acute ischemic stroke; mRS, modified Rankin Scale; LVO, large vessel occlusion; ASPECTS, Alberta stroke program early CT score; EVT, endovascular treatment; TTM, targeted temperature management; IV, intravenous; rtPA, recombinant tissue plasminogen activator; MCA, middle cerebral artery; CT, computed tomography; MRI, magnetic resonance imaging; ASIAN KR, Acute Stroke due to Intracranial Atherosclerotic occlusion and Neurointervention Korean Retrospective. 
to prevent unwanted effects in those patients.

\section{Reperfusion injury and neuroprotection study}

In terms of the pathobiology of cerebral infarction, a cascade of cellular changes, including excitotoxicity, peri-infarct depolarization, inflammation, and apoptosis, are involved. ${ }^{147}$ Glutamate release via the $\mathrm{N}$-methyl-D-aspartate (NMDA) receptor and free radicals, which are related to reperfusion injury, is known as an essential pathophysiologic mechanism in ischemia/reperfusion models, and is a target for neuroprotective treatment. ${ }^{147}$ In the era of modern thrombectomy, reperfusion injury might be masked due to improved clinical outcomes, and neuroprotective treatment might be necessary in specific situations. Various representative neuroprotective studies for patients with acute stroke, which were performed before and after the EVT era, are summarized in Table 3. ${ }^{14,148-153}$

Previously, NXY-059, a neuroprotective agent with free radical-trapping properties showed a huge protective effect on rodent models with cerebral ischemia. ${ }^{154}$ A clinical trial, SAINT I study, showed an improvement of mRS in the NXY-059 group whereas change from baseline in total National Institute of Health Stroke Scale (NIHSS) score, another co-primary endpoint, did not differ from the placebo group. ${ }^{155}$ Finally, the next SAINT II study failed to prove the neuroprotective effect between the NXY-059 and placebo groups. ${ }^{148}$ After this failure, all neuroprotective studies and investments were discouraged. It is suspected that the inconsistent results of neuroprotective treatment came from differences between animal studies and clinical settings. In the SAINT trials, patients were enrolled if they had acute ischemic stroke. ${ }^{148,155}$ The population, however, was highly heterogeneous because they were not differentiated based on the severity of the stroke and the size of occlusive vessels. Thus, the study would include diverse subjects with mild, moderate, or severe stroke, and the occlusion of the cerebral artery might occur in small branches or large vessels. In addition, only a small portion of the LVO was reperfused in the pre-MT era. In contrast, LVO is mostly involved in the proximal middle cerebral artery (MCA) through the ICA and is always completely recanalized and reperfused within a few hours (mostly 2 hours) in rodent models. ${ }^{156}$ Furthermore, very young animals were used for the experiments. ${ }^{157}$ It is believed that these differences had contributed to the inconsistent result and the failure in clinical trials. However, it is time for neuroprotection to be revisited. In the current thrombectomy era, successful reperfusion among patients with LVO is much more frequent than that in the pre-MT era, although complete reperfusion is still challenging. ${ }^{65,158-160}$ Now, the characteristics of patients with LVO are more similar to those of cerebral ischemia animal models.

The very recent ESCAPE-NA1 trial is an RCT for evaluating the efficacy and safety of a neuroprotective agent in the modern thrombectomy era. ${ }^{149}$ NA1 (nerinetide, or Tat-NR2B9c), used in the trial, interferes with post-synaptic protein 95 and perturbs the interactions between the protein and NMDA receptor, thereby ameliorating the glutamate toxicity of the ischemic brain and reducing infarct volume in both permanent and transient focal ischemia models. ${ }^{161,162}$ In the previous ENACT study, a phase II trial, no serious adverse events were reported in 92 patients from the NA1 group, although the lesion volume as observed by MRI did not differ between the NA1 and placebo groups. ${ }^{163}$ The final results of the ESCAPE-NA1 trial failed to prove the efficacy of NA1 on clinical outcomes after EVT for patients with AIS and LVO. ${ }^{149}$ In a subgroup analysis, an interaction was shown between alteplase and the efficacy of NA1 administration. It appeared that NA1 was effective in patients without alteplase. ${ }^{149}$ In reality, alteplase inhibited NA1 levels, ${ }^{164}$ and this could be a possible explanation for the failure of the ESCAPE-NA trial. ${ }^{165}$ However, it is thought that too good clinical outcomes in the placebo group were the main reason behind the failure. Based upon similar (onset to randomization up to 12 hours) or slightly wider inclusion criteria than that compared with the ESCAPE trial (ASPECTS 5 to 10 in ESCAPE NA1 vs. ASPECTS 6 to 10 in ESCAPE), the rate of good clinical outcomes was higher in the ESCAPE-NA1 placebo group than in the ESCAPE treatment group (59.2\% vs. 53.0\%). ${ }^{19,149}$ Now, a new successive trial, ESCAPE NEXT, is being launched (ClinicalTrials.gov Identifier: NCT04462536). The candidates will be randomized for nerinetide without alteplase infusion with a protocol similar to that of ESCAPE-NA1. We hope that this will succeed.

Neu2000 (nelonemdaz) is another neuroprotective agent, which is a cocktail regimen with both NMDA antagonistic and antioxidant actions. ${ }^{166,167}$ The drug awaits the reports from the phase II trial. ${ }^{150}$ We hope additional neuroprotective agents would help in improving the clinical outcomes in serious stroke patients.

Therapeutic hypothermia, a targeted temperature management (TTM), is another neuroprotective method. It is a specified composite of management but does not use a specific drug. The key mechanisms of action include the 
inhibition of excitotoxicity, neuroinflammation, apoptosis, free radical production, and so on. ${ }^{168} \mathrm{~A}$ decrease in cerebral energy metabolism is another main mechanism of TTM neuroprotective effects. ${ }^{169}$ The TTM has already been approved as a neuroprotective treatment in comatose patients with return of spontaneous circulation after cardiac arrest. ${ }^{170-172}$ These patients are in line with the ischemia/reperfusion model. On this ground, TTM has been mentioned as a promising treatment strategy for patients with acute ischemic stroke and has been evaluated in various studies (Table 3). ${ }^{173}$ Contradicting our expectations, most RCTs for TTM have failed to prove the improvement of clinical outcomes in patients with acute ischemic stroke. ${ }^{151,152,174}$ In contrast, the HARIS study, a case-control study, did show an improvement in clinical outcomes and the reduction of cerebral edema and hemorrhagic transformation in the TTM group versus the control group. ${ }^{153}$ The median ASPECTS was 6 in the TTM group, which means that included patients had moderate to severe stroke severity. ${ }^{153}$ Interestingly, only patients who had successful reperfusion from EVT were included, similarly as ischemia/reperfusion models. ${ }^{153}$ From the ASIAN KR registry, similar results were reported. ${ }^{14}$ In the overall population with LVO and EVT, the clinical outcomes did not differ between the TTM and control groups. ${ }^{14}$ However, a significantly higher rate of good clinical outcomes (32.1\% vs. 7.7\%) was revealed from TTM in the malignant trait subgroup, which was designated as baseline ASPECTS $<6$, DWI lesion volume $>82 \mathrm{~mL}$, or NIHSS $>20 .^{14}$

To summarize the results from neuroprotective studies in a stroke population, essential points for trial success appear to include (1) reperfusion by EVT in patients with emergent LVO and (2) patients with a relatively malignant stroke profile or with poor prognostic factors.

\section{CONCLUSION}

The current review article was based on the results of the ASIAN KR registry studies. The most important issues and considerations regarding EVT for emergent LVO were covered. Although Asian patients were rarely included in the RCTs for EVT that were reported earlier, the obtained data from Asian registry studies were found to be comparable to the outcomes of RCTs. Besides, with respect to the Asian subjects, EVT was observed to be more efficacious against ICAS LVO when compared with embolic LVO, which is pri- marily detected in patients from Western countries. Fast and complete reperfusion should be an ultimate target of EVT since it is closely related to good outcomes as demonstrated by diffusion reversal. Patients with diabetes should be cautiously treated because they have a potential risk of poor clinical outcomes, hemorrhagic transformation, and acute kidney injury after EVT. Treatment of reperfusion injury in patients with poor prognostic factors should be further studied to determine if the prognosis could be improved by both EVT and neuroprotection treatment. Cumulatively, with these factors contributing to EVT outcomes and clinical implications, EVT can lead to a better prognosis in patients with AIS and LVO.

\section{Acknowledgments}

We sincerely thank all other ASIAN KR collaborators, including professors Ji Man Hong, Seong-Joon Lee, Jin Wook Choi (Ajou University), Dong-Hun Kang, Yong-Won Kim, Yong-Sun Kim (Kyungpook National University), Jeong-Ho Hong, ChangHyun Kim (Keimyung University), Joonsang Yoo (Yonsei University), Andrew M. Demchuk (University of Calgary), Bruce Ovbiagele (University of California), and Raul G. Nogueira (Emory University).

\section{Fund}

This work was partly supported by the National Research Foundation of Korea (NRF) Grant funded by the Korea Government (MSIP) (NRF-2018R1A2B6007094; JSL).

\section{Ethics Statement}

The approval of the institutional ethics committee and informed consents were waived since its nature lies on literature review.

\section{Conflicts of Interest}

The authors have no conflicts to disclose.

\section{Author Contributions}

Concept and design: JSL. Analysis and interpretation: JSL. Data collection: JSL. Writing the article: JSL. Critical revision of the article: JSL, YH, and SS. Final approval of the article: JSL, YH, and SS. Statistical analysis: JSL. Obtained funding: JSL. Overall responsibility: JSL.

\section{ORCID}

Jin Soo Lee: https://orcid.org/0000-0002-7225-6166 
Yang-Ha Hwang: https://orcid.org/0000-0002-6665-7481

Sung-II Sohn: https://orcid.org/0000-0002-6900-1242

\section{REFERENCES}

1. Lee JS, Lee SJ, Hong JM, Choi JW, Hong JH, Chang HW, et al. Temporal changes in care processes and outcomes for endovascular treatment of acute ischemic stroke: retrospective registry data from three Korean centers. Neurointervention 2018;13:2-12

2. Lee SJ, Hong JM, Choi JW, Park JH, Park B, Kang DH, et al. Predicting endovascular treatment outcomes in acute vertebrobasilar artery occlusion: a model to aid patient selection from the Asian KR registry. Radiology 2020;294:628-637

3. Lee SJ, Hong JM, Choi JW, Kang DH, Kim YW, Kim YS, et al. CTAbased truncal-type occlusion is best matched with postprocedural fixed focal stenosis in vertebrobasilar occlusions. Front Neurol 2019;9:1195

4. Lee JS, Lee SJ, Yoo JS, Hong JH, Kim CH, Kim YW, et al. Prognosis of acute intracranial atherosclerosis-related occlusion after endovascular treatment. J Stroke 2018;20:394-403

5. Lee SJ, Hwang YH, Hong JM, Choi JW, Kang DH, Kim YW, et al. Predictors and prognoses of Willisian collateral failure during mechanical thrombectomy. Sci Rep 2020;10:20874

6. Lee JS, Lee SJ, Hong JM, Choi JW, Yoo J, Hong JH, et al. Solitaire thrombectomy for acute stroke due to intracranial atherosclerosis-related occlusion: ROSE ASSIST study. Front Neurol 2018;9:1064

7. Yoo J, Lee SJ, Hong JH, Kim YW, Hong JM, Kim CH, et al. Immediate effects of first-line thrombectomy devices for intracranial atherosclerosis-related occlusion: stent retriever versus contact aspiration. BMC Neurol 2020;20:283

8. Kim YW, Sohn SI, Yoo J, Hong JH, Kim CH, Kang DH, et al. Local tirofiban infusion for remnant stenosis in large vessel occlusion: tirofiban ASSIST study. BMC Neurol 2020;20:284

9. Lee SJ, Park SY, Hong JM, Choi JW, Kang DH, Kim YW, et al. Etiological approach to understanding recanalization failure in intracranial large vessel occlusion and thrombectomy: close to embolism but distant from atherosclerosis. Front Neurol 2021;11:598216

10. Min JH, Lee SJ, Hong JM, Choi JW, Kang DH, Kim YW, et al. Clinical impact of intracerebral hemorrhage after hyperacute extracranial stenting in patients with ischemic stroke. Neurointervention 2019;14:107-115

11. Yoo J, Choi JW, Lee SJ, Hong JM, Hong JH, Kim CH, et al. Ischemic diffusion lesion reversal after endovascular treatment.
Stroke 2019;50:1504-1509

12. Lee SJ, Hwang YH, Hong JM, Choi JW, Yoon BS, Kang DH, et al. Impact of varying levels of hyperglycemia on clinicoradiographic outcomes after endovascular reperfusion treatment. Sci Rep 2018;8:9832

13. Yoo J, Hong JH, Lee SJ, Kim YW, Hong JM, Kim CH, et al. Acute kidney injury after endovascular treatment in patients with acute ischemic stroke. J Clin Med 2020;9:1471

14. Choi MH, Gil YE, Lee SJ, Lee JS, Hong JH, Sohn SI, et al. The clinical usefulness of targeted temperature management in acute ischemic stroke with malignant trait after endovascular thrombectomy. [published online ahead of print Aug 18, 2020] Neurocrit Care 2020

15. Broderick JP, Palesch YY, Demchuk AM, Yeatts SD, Khatri P, Hill MD, et al.; Interventional Management of Stroke (IMS) III Investigators. Endovascular therapy after intravenous t-PA versus t-PA alone for stroke. N Engl J Med 2013;368:893-903

16. Kidwell CS, Jahan R, Gornbein J, Alger JR, Nenov V, Ajani Z, et al.; MR RESCUE Investigators. A trial of imaging selection and endovascular treatment for ischemic stroke. N Engl J Med 2013;368:914-923

17. Ciccone A, Valvassori L, Nichelatti M, Sgoifo A, Ponzio M, Sterzi $\mathrm{R}$, et al.; SYNTHESIS Expansion Investigators. Endovascular treatment for acute ischemic stroke. N Engl J Med 2013;368:904-913

18. Berkhemer OA, Fransen PS, Beumer D, van den Berg LA, Lingsma HF, Yoo AJ, et al.; MR CLEAN Investigators. A randomized trial of intraarterial treatment for acute ischemic stroke. N Engl J Med 2015;372:11-20

19. Goyal M, Demchuk AM, Menon BK, Eesa M, Rempel JL, Thornton J, et al.; ESCAPE Trial Investigators. Randomized assessment of rapid endovascular treatment of ischemic stroke. N Engl J Med 2015;372:1019-1030

20. Saver UL, Goyal M, Bonafe A, Diener HC, Levy El, Pereira VM, et al.; SWIFT PRIME Investigators. Stent-retriever thrombectomy after intravenous t-PA vs. t-PA alone in stroke. N Engl J Med 2015;372: 2285-2295

21. Campbell BC, Mitchell PJ, Kleinig TJ, Dewey HM, Churilov L, Yassi $\mathrm{N}$, et al.; EXTEND-IA Investigators. Endovascular therapy for ischemic stroke with perfusion-imaging selection. N Engl J Med 2015;372:1009-1018

22. Jovin TG, Chamorro A, Cobo E, de Miquel MA, Molina CA, Rovira A, et al.; REVASCAT Trial Investigators. Thrombectomy within 8 hours after symptom onset in ischemic stroke. N Engl J Med 2015;372:2296-2306

23. Goyal M, Yu AY, Menon BK, Dippel DW, Hacke W, Davis SM, et al. Endovascular therapy in acute ischemic stroke: challenges and 
transition from trials to bedside. Stroke 2016;47:548-553

24. Powers WJ, Derdeyn CP, Biller J, Coffey CS, Hoh BL, Jauch EC, et al.; American Heart Association Stroke Council. 2015 American Heart Association/American Stroke Association focused update of the 2013 guidelines for the early management of patients with acute ischemic stroke regarding endovascular treatment: a guideline for healthcare professionals from the American Heart Association/American Stroke Association. Stroke 2015;46:30203035

25. Hong KS, Ko SB, Yu KH, Jung C, Park SQ, Kim BM, et al. Update of the Korean clinical practice guidelines for endovascular recanalization therapy in patients with acute ischemic stroke. J Stroke 2016;18:102-113

26. Connolly SJ, Ezekowitz MD, Yusuf S, Eikelboom J, Oldgren J, Parekh A, et al.; RE-LY Steering Committee and Investigators. Dabigatran versus warfarin in patients with atrial fibrillation. $N$ Eng/ J Med 2009;361:1139-1151

27. Patel MR, Mahaffey KW, Garg J, Pan G, Singer DE, Hacke W, et al.; ROCKET AF Investigators. Rivaroxaban versus warfarin in nonvalvular atrial fibrillation. N Engl J Med 2011;365:883-891

28. Granger CB, Alexander JH, McMurray JJ, Lopes RD, Hylek EM, Hanna M, et al.; ARISTOTLE Committees and Investigators. Apixaban versus warfarin in patients with atrial fibrillation. N Engl J Med 2011;365:981-992

29. Giugliano RP, Ruff CT, Braunwald E, Murphy SA, Wiviott SD, Halperin JL, et al.; ENGAGE AF-TIMI 48 Investigators. Edoxaban versus warfarin in patients with atrial fibrillation. N Engl J Med 2013;369:2093-2104

30. Park SJ, Shim WH, Ho DS, Raizner AE, Park SW, Hong MK, et al. A paclitaxel-eluting stent for the prevention of coronary restenosis. N Engl J Med 2003;348:1537-1545

31. Seung KB, Park DW, Kim YH, Lee SW, Lee CW, Hong MK, et al. Stents versus coronary-artery bypass grafting for left main coronary artery disease. N Engl J Med 2008;358:1781-1792

32. Park SJ, Kim YH, Park DW, Yun SC, Ahn JM, Song HG, et al. Randomized trial of stents versus bypass surgery for left main coronary artery disease. N Engl J Med 2011;364:1718-1727

33. Nogueira RG, Jadhav AP, Haussen DC, Bonafe A, Budzik RF, Bhuva P, et al.; DAWN Trial Investigators. Thrombectomy 6 to 24 hours after stroke with a mismatch between deficit and infarct. NEngl J Med 2018;378:11-21

34. Albers GW, Marks MP, Kemp S, Christensen S, Tsai JP, Ortega-Gutierrez S, et al.; DEFUSE 3 Investigators. Thrombectomy for stroke at 6 to 16 hours with selection by perfusion imaging. $N$ Engl J Med 2018;378:708-718

35. Liu X, Dai Q, Ye R, Zi W, Liu Y, Wang H, et al.; BEST Trial Investi- gators. Endovascular treatment versus standard medical treatment for vertebrobasilar artery occlusion (BEST): an open-label, randomised controlled trial. Lancet Neurol 2020;19:115-122

36. Schonewille W; BASICS study group. The Basilar Artery International Collaboration Study (BASICS): a randomized controlled trial of endovascular therapy in basilar artery occlusion. Paper presented at: the Joint European Stroke Organisation and World Stroke Organization Conference (ESO-WSO 2020); 2020 Nov 7-9; Vienna, Austria. Geneva: World Stroke Organization, 2020. p. 5

37. Kim BM, Baek JH, Heo JH, Nam HS, Kim YD, Yoo J, et al. Collateral status affects the onset-to-reperfusion time window for good outcome. J Neurol Neurosurg Psychiatry 2018;89:903-909

38. Kim YD, Heo JH, Yoo J, Park H, Kim BM, Bang OY, et al. Improving the clinical outcome in stroke patients receiving thrombolytic or endovascular treatment in Korea: from the SECRET study. J Clin Med 2020;9:717

39. Kang DH, Jung C, Yoon W, Kim SK, Baek BH, Kim JT, et al. Endovascular thrombectomy for acute basilar artery occlusion: a multicenter retrospective observational study. J Am Heart Assoc 2018;7:e009419

40. Lee JS, Hong JM, Kim JS. Diagnostic and Therapeutic Strategies for Acute Intracranial Atherosclerosis-related Occlusions. J Stroke 2017;19:143-151

41. Koh S, Park JH, Park B, Choi MH, Lee SE, Lee JS, et al. Prediction of infarct growth and neurological deterioration in patients with vertebrobasilar artery occlusions. J Clin Med 2020;9:3759

42. Kim YW, Hong JM, Park DG, Choi JW, Kang DH, Kim YS, et al. Effect of intracranial atherosclerotic disease on endovascular treatment for patients with acute vertebrobasilar occlusion. AJNR Am J Neuroradiol 2016;37:2072-2078

43. Powers WJ, Rabinstein AA, Ackerson T, Adeoye OM, Bambakidis NC, Becker K, et al. Guidelines for the early management of patients with acute ischemic stroke: 2019 update to the 2018 guidelines for the early management of acute ischemic stroke: a guideline for healthcare professionals from the American Heart Association/American Stroke Association. Stroke 2019;50:e344-e418

44. Ko SB, Park HK, Kim BM, Heo JH, Rha JH, Kwon SU, et al. 2019 Update of the Korean clinical practice guidelines of stroke for endovascular recanalization therapy in patients with acute ischemic stroke. J Stroke 2019;21:231-240

45. Kim BJ, Kim JS. Ischemic stroke subtype classification: an Asian viewpoint. J Stroke 2014;16:8-17

46. Sacco RL, Kargman DE, Gu Q, Zamanillo MC. Race-ethnicity and determinants of intracranial atherosclerotic cerebral infarction. The Northern Manhattan stroke study. Stroke 1995;26:14-20 
47. Ratanakorn D, Keandoungchun J, Tegeler CH. Coexistent extraand intracranial stenosis, cervical atherosclerosis, and abnormal ankle brachial index in acute ischemic stroke. J Stroke Cerebrovasc Dis 2012;21:782-789

48. Kim JS, Kim YJ, Ahn SH, Kim BJ. Location of cerebral atherosclerosis: why is there a difference between East and West? Int J Stroke 2018;13:35-46

49. Baek JH, Kim BM, Heo JH, Kim DJ, Nam HS, Kim YD. Outcomes of endovascular treatment for acute intracranial atherosclerosis-related large vessel occlusion. Stroke 2018;49:2699-2705

50. Suh HI, Hong JM, Lee KS, Han M, Choi JW, Kim JS, et al. Imaging predictors for atherosclerosis-related intracranial large artery occlusions in acute anterior circulation stroke. J Stroke 2016;18:352-354

51. Lee YY, Yoon W, Kim SK, Baek BH, Kim GS, Kim JT, et al. Acute basilar artery occlusion: differences in characteristics and outcomes after endovascular therapy between patients with and without underlying severe atherosclerotic stenosis. AJNR Am J Neuroradiol 2017;38:1600-1604

52. Baek JH, Kim BM, Heo JH, Kim DJ, Nam HS, Kim YD. Endovascular and clinical outcomes of vertebrobasilar intracranial atherosclerosis-related large vessel occlusion. Front Neurol 2019;10:215

53. Li H, Zhang Y, Zhang L, Li Z, Xing P, Zhang Y, et al. Endovascular treatment of acute ischemic stroke due to intracranial atherosclerotic large vessel occlusion : a systematic review. Clin Neuroradiol 2020;30:777-787

54. Tsang ACO, Orru E, Klostranec JM, Yang IH, Lau KK, Tsang FCP, et al. Thrombectomy outcomes of intracranial atherosclerosis-related occlusions. Stroke 2019;50:1460-1466

55. Saver JL, Jahan R, Levy El, Jovin TG, Baxter B, Nogueira RG, et al.; SWIFT Trialists. Solitaire flow restoration device versus the Merci Retriever in patients with acute ischaemic stroke (SWIFT): a randomised, parallel-group, non-inferiority trial. Lancet 2012;380: 1241-1249

56. Nogueira RG, Lutsep HL, Gupta R, Jovin TG, Albers GW, Walker GA, et al.; TREVO 2 Trialists. Trevo versus Merci Retrievers for thrombectomy revascularisation of large vessel occlusions in acute ischaemic stroke (TREVO 2): a randomised trial. Lancet 2012;380:1231-1240

57. Kang DH, Hwang YH, Kim YS, Park J, Kwon O, Jung C. Direct thrombus retrieval using the reperfusion catheter of the penumbra system: forced-suction thrombectomy in acute ischemic stroke. AJNR Am J Neuroradiol 2011;32:283-287

58. Turk AS, Frei D, Fiorella D, Mocco J, Baxter B, Siddiqui A, et al. ADAPT FAST study: a direct aspiration first pass technique for acute stroke thrombectomy. J Neurointerv Surg 2014;6:260-264
59. Nguyen TN, Malisch T, Castonguay AC, Gupta R, Sun CH, Martin $\mathrm{CO}$, et al. Balloon guide catheter improves revascularization and clinical outcomes with the Solitaire device: analysis of the North American Solitaire Acute Stroke registry. Stroke 2014;45:141-145

60. Kang DH, Kim BM, Heo JH, Nam HS, Kim YD, Hwang YH, et al. Effect of balloon guide catheter utilization on contact aspiration thrombectomy. [published online ahead of print Nov 1, 2018] J Neurosurg 2018

61. Kim YW, Kang DH, Hwang YH, Park J, Kim YS. Efficacy of proximal aspiration thrombectomy for using balloon-tipped guide catheter in acute intracranial internal carotid artery occlusion. $J$ Korean Neurosurg Soc 2016;59:379-384

62. Baek JH, Kim BM, Kang DH, Heo JH, Nam HS, Kim YD, et al. Balloon guide catheter is beneficial in endovascular treatment regardless of mechanical recanalization modality. Stroke 2019;50:1490-1496

63. Klinger-Gratz PP, Schroth G, Gralla J, Jung S, Weisstanner C, Verma RK, et al. Protected stent retriever thrombectomy prevents iatrogenic emboli in new vascular territories. Neuroradiology 2015;57:1045-1054

64. Alverne FJAM, Lima FO, Rocha FA, Bandeira DA, Lucena AF, Silva $H C$, et al. Unfavorable vascular anatomy during endovascular treatment of stroke: challenges and bailout strategies. J Stroke 2020;22:185-202

65. Yoo AJ, Andersson T. Thrombectomy in acute ischemic stroke: challenges to procedural success. J Stroke 2017;19:121-130

66. Klisch J, Sychra V, Strasilla C, Taschner CA, Reinhard M, Urbach $\mathrm{H}$, et al. Double solitaire mechanical thrombectomy in acute stroke: effective rescue strategy for refractory artery occlusions? AJNR Am J Neuroradio/ 2015;36:552-556

67. Aydin K, Barburoglu M, Oztop Cakmak O, Yesilot N, Vanli ENY, Akpek S. Crossing Y-Solitaire thrombectomy as a rescue treatment for refractory acute occlusions of the middle cerebral artery. J Neurointerv Surg 2019;11:246-250

68. Lee JS, Hong JM, Lee KS, Suh HI, Choi JW, Kim SY. Primary stent retrieval for acute intracranial large artery occlusion due to atherosclerotic disease. J Stroke 2016;18:96-101

69. Kang DH, Yoon W, Baek BH, Kim SK, Lee YY, Kim JT, et al. Frontline thrombectomy for acute large-vessel occlusion with underlying severe intracranial stenosis: stent retriever versus contact aspiration. J Neurosurg 2019;132:1202-1208

70. Kang DH, Hwang YH. Frontline contact aspiration treatment for emergent large vessel occlusion: a review focused on practical techniques. J Stroke 2019;21:10-22

71. Heo JH, Lee KY, Kim SH, Kim DI. Immediate reocclusion following a successful thrombolysis in acute stroke: a pilot study. Neu- 
rology 2003;60:1684-1687

72. Kwon OK, Lee KJ, Han MH, Oh CW, Han DH, Koh YC. Intraarterially administered abciximab as an adjuvant thrombolytic therapy: report of three cases. AJNR Am J Neuroradiol 2002;23:447451

73. Baik SK, Oh SJ, Park KP, Lee JH. Intra-arterial tirofiban infusion for partial recanalization with stagnant flow in hyperacute cerebral ischemic stroke. Interv Neuroradiol 2011;17:442-451

74. Kang DH, Kim YW, Hwang YH, Park SP, Kim YS, Baik SK. Instant reocclusion following mechanical thrombectomy of in situ thromboocclusion and the role of low-dose intra-arterial tirofiban. Cerebrovasc Dis 2014;37:350-355

75. Yoon W, Kim SK, Park MS, Kim BC, Kang HK. Endovascular treatment and the outcomes of atherosclerotic intracranial stenosis in patients with hyperacute stroke. Neurosurgery 2015;76:680686

76. Kim JG, Suh DC, Song Y, Choi JC, Lee DH. Direct stenting of intracranial atherosclerosis-related acute large vessel occlusion. [published online ahead of print Jul 30, 2020] Clin Neuroradiol 2020

77. Baek JH, Kim BM, Kim DJ, Heo JH, Nam HS, Yoo J. Stenting as a rescue treatment after failure of mechanical thrombectomy for anterior circulation large artery occlusion. Stroke 2016;47:23602363

78. Chang Y, Kim BM, Bang OY, Baek JH, Heo JH, Nam HS, et al. Rescue stenting for failed mechanical thrombectomy in acute ischemic stroke: a multicenter experience. Stroke 2018;49:958964

79. Maingard J, Phan K, Lamanna A, Kok HK, Barras CD, Russell J, et al. Rescue intracranial stenting after failed mechanical thrombectomy for acute ischemic stroke: a systematic review and meta-analysis. World Neurosurg 2019;132:e235-e245

80. Papanagiotou P, Roth C, Walter S, Behnke S, Grunwald IQ, Viera J, et al. Carotid artery stenting in acute stroke. J Am Coll Cardiol 2011;58:2363-2369

81. Anadani M, Spiotta AM, Alawieh A, Turjman F, Piotin M, Haussen DC, et al.; TITAN (Thrombectomy In TANdem Lesions) Investigators. Emergent carotid stenting plus thrombectomy after thrombolysis in tandem strokes: analysis of the TITAN registry. Stroke 2019;50:2250-2252

82. Rodrigues M, Cunha A, Figueiredo S, Carvalho A, Veloso M, Barros $P$, et al. Emergent carotid artery stenting in atherosclerotic disease of the internal carotid artery with tandem intracranial occlusion. J Neurol Sci 2018;387:196-198

83. Saver JL. Time is brain--quantified. Stroke 2006;37:263-266

84. Saver JL, Goyal M, van der Lugt A, Menon BK, Majoie CB, Dippel
DW, et al.; HERMES Collaborators. Time to treatment with endovascular thrombectomy and outcomes from ischemic stroke: a meta-analysis. JAMA 2016;316:1279-1288

85. Bang OY, Saver JL, Buck BH, Alger JR, Starkman S, Ovbiagele B, et al.; UCLA Collateral Investigators. Impact of collateral flow on tissue fate in acute ischaemic stroke. J Neurol Neurosurg Psychiatry 2008;79:625-629

86. Liebeskind DS. Collateral lessons from recent acute ischemic stroke trials. Neurol Res 2014;36:397-402

87. Hwang YH, Kang DH, Kim YW, Kim YS, Park SP, Liebeskind DS. Impact of time-to-reperfusion on outcome in patients with poor collaterals. AJNR Am J Neuroradiol 2015;36:495-500

88. Lee SU, Hong JM, Kim SY, Bang OY, Demchuk AM, Lee JS. Differentiating carotid terminus occlusions into two distinct populations based on willisian collateral status. J Stroke 2016;18:179186

89. Kim DH, Kim B, Jung C, Nam HS, Lee JS, Kim JW, et al. Consensus statements by Korean Society of Interventional Neuroradiology and Korean Stroke Society: hyperacute endovascular treatment workflow to reduce door-to-reperfusion time. Korean J Radiol 2018;19:838-848

90. Lee D, Lee DH, Suh DC, Kim BJ, Kwon SU, Kwon HS, et al. Endovascular treatment in patients with cerebral artery occlusion of three different etiologies. J Stroke 2020;22:234-244

91. Demchuk AM, Goyal M, Menon BK, Eesa M, Ryckborst KJ, Kamal $\mathrm{N}$, et al.; ESCAPE Trial Investigators. Endovascular treatment for Small Core and Anterior circulation Proximal occlusion with Emphasis on minimizing CT to recanalization times (ESCAPE) trial: methodology. Int J Stroke 2015;10:429-438

92. Choi MH, Lim TS, Yoon BS, Son KS, Hong JM, Lee JS. Low testosterone level as a predictor of poststroke emotional disturbances: anger proneness and emotional incontinence. J Stroke Cerebrovasc Dis 2018:27:3549-3554

93. Ribo M, Molina CA, Cobo E, Cerdà N, Tomasello A, Quesada H, et al.; REVASCAT Trial Investigators. Association between time to reperfusion and outcome is primarily driven by the time from imaging to reperfusion. Stroke 2016;47:999-1004

94. Tsai JP, Mlynash M, Christensen S, Kemp S, Kim S, Mishra NK, et al.; CRISP Investigators. Time from imaging to endovascular reperfusion predicts outcome in acute stroke. Stroke 2018;49: 952-957

95. Loubinoux I, Volk A, Borredon J, Guirimand S, Tiffon B, Seylaz $J$, et al. Spreading of vasogenic edema and cytotoxic edema assessed by quantitative diffusion and T2 magnetic resonance imaging. Stroke 1997;28:419-426; discussion 426-427

96. Hossmann KA, Fischer M, Bockhorst K, Hoehn-Berlage M. NMR 
imaging of the apparent diffusion coefficient (ADC) for the evaluation of metabolic suppression and recovery after prolonged cerebral ischemia. J Cereb Blood Flow Metab 1994;14:723-731

97. Han M, Choi JW, Rim NJ, Kim SY, Suh HI, Lee KS, et al. Cerebral infarct volume measurements to improve patient selection for endovascular treatment. Medicine (Baltimore) 2016;95:e4702

98. Sakamoto Y, Kimura K, Shibazaki K, Inoue T, Uemura J, Aoki J, et al. Early ischaemic diffusion lesion reduction in patients treated with intravenous tissue plasminogen activator: infrequent, but significantly associated with recanalization. Int I Stroke 2013;8:321-326

99. Zaidat OO, Castonguay AC, Linfante I, Gupta R, Martin CO, Holloway WE, et al. First pass effect: a new measure for stroke thrombectomy devices. Stroke 2018;49:660-666

100. Chamorro Á, Blasco J, López A, Amaro S, Román LS, Llull L, et al. Complete reperfusion is required for maximal benefits of mechanical thrombectomy in stroke patients. Sci Rep 2017;7:11636

101. Kleine JF, Wunderlich S, Zimmer C, Kaesmacher J. Time to redefine success? $\mathrm{TICl} 3$ versus $\mathrm{TICl} 2 \mathrm{~b}$ recanalization in middle cerebral artery occlusion treated with thrombectomy. J Neurointerv Surg 2017;9:117-121

102. Tung EL, McTaggart RA, Baird GL, Yaghi S, Hemendinger M, Dibiasio $\mathrm{EL}$, et al. Rethinking thrombolysis in cerebral infarction 2b: which thrombolysis in cerebral infarction scales best define near complete recanalization in the modern thrombectomy era? Stroke 2017:48:2488-2493

103. Dargazanli C, Fahed R, Blanc R, Gory B, Labreuche J, Duhamel A, et al.; ASTER Trial Investigators. Modified Thrombolysis in Cerebral Infarction 2C/Thrombolysis in Cerebral Infarction 3 reperfusion should be the aim of mechanical thrombectomy: insights from the ASTER trial (Contact Aspiration Versus Stent Retriever for Successful Revascularization). Stroke 2018;49:1189-1196

104. Kaesmacher J, Dobrocky T, Heldner MR, Bellwald S, Mosimann PJ, Mordasini P, et al. Systematic review and meta-analysis on outcome differences among patients with $\mathrm{TICl} 2 \mathrm{~b}$ versus $\mathrm{TICl} 3$ reperfusions: success revisited. J Neurol Neurosurg Psychiatry 2018;89:910-917

105. Parsons MW, Barber PA, Desmond PM, Baird TA, Darby DG, Byrnes $G$, et al. Acute hyperglycemia adversely affects stroke outcome: a magnetic resonance imaging and spectroscopy study. Ann Neurol 2002;52:20-28

106. Dávalos A, Toni D, Iweins F, Lesaffre E, Bastianello S, Castillo J. Neurological deterioration in acute ischemic stroke: potential predictors and associated factors in the European cooperative acute stroke study (ECASS) I. Stroke 1999;30:2631-2636

107. Lansberg MG, Albers GW, Wijman CA. Symptomatic intrace- rebral hemorrhage following thrombolytic therapy for acute ischemic stroke: a review of the risk factors. Cerebrovasc Dis 2007;24:1-10

108. Lee SJ, Hong JM, Lee SE, Kang DR, Ovbiagele B, Demchuk AM, et al. Association of fibrinogen level with early neurological deterioration among acute ischemic stroke patients with diabetes. BMC Neurol 2017;17:101

109. Summary information on a referral opinion following an arbitration pursuant to Article 29 of Directive 2001/83/ec, for Actilyse [Internet]. London: European Medicines Agency; 2002 Nov 21 [cited 2020 Sep 7]. Available from: http://www.ema.europa. eu/docs/en_GB/document_library/Referrals_document/Actilyse_29/WC500010327.pdf

110. Hacke W, Albers G, Al-Rawi Y, Bogousslavsky J, Davalos A, Eliasziw M, et al.; DIAS Study Group. The Desmoteplase in Acute Ischemic Stroke Trial (DIAS): a phase II MRI-based 9-hour window acute stroke thrombolysis trial with intravenous desmoteplase. Stroke 2005;36:66-73

111. Ehrlich ME, Liang L, Xu H, Kosinski AS, Hernandez AF, Schwamm $\mathrm{LH}$, et al. Intravenous tissue-type plasminogen activator in acute ischemic stroke patients with history of stroke plus diabetes mellitus. Stroke 2019:50:1497-1503

112. Demchuk AM, Morgenstern LB, Krieger DW, Linda Chi T, Hu W, Wein TH, et al. Serum glucose level and diabetes predict tissue plasminogen activator-related intracerebral hemorrhage in acute ischemic stroke. Stroke 1999;30:34-39

113. Furlan A, Higashida R, Wechsler L, Gent M, Rowley H, Kase C, et al. Intra-arterial prourokinase for acute ischemic stroke. The PROACT II study: a randomized controlled trial. Prolyse in Acute Cerebral Thromboembolism. JAMA 1999;282:2003-2011

114. Kase CS, Furlan AJ, Wechsler LR, Higashida RT, Rowley HA, Hart $R G$, et al. Cerebral hemorrhage after intra-arterial thrombolysis for ischemic stroke: the PROACT II trial. Neurology 2001;57:16031610

115. Wei J, Huang NC, Quast MJ. Hydroxyl radical formation in hyperglycemic rats during middle cerebral artery occlusion/ reperfusion. Free Radic Biol Med 1997;23:986-995

116. Quast MJ, Wei J, Huang NC, Brunder DG, Sell SL, Gonzalez JM, et al. Perfusion deficit parallels exacerbation of cerebral ischemia/ reperfusion injury in hyperglycemic rats. J Cereb Blood Flow Metab 1997;17:553-559

117. Osei E, den Hertog HM, Berkhemer OA, Fransen PS, Roos YB, Beumer $D$, et al.; MR CLEAN pretrial investigators. Increased admission and fasting glucose are associated with unfavorable short-term outcome after intra-arterial treatment of ischemic stroke in the MR CLEAN pretrial cohort. J Neurol Sci 2016;371:1-5 
118. Kruyt ND, Biessels GJ, Devries JH, Roos YB. Hyperglycemia in acute ischemic stroke: pathophysiology and clinical management. Nat Rev Neurol 2010;6:145-155

119. Johnston KC, Bruno A, Pauls Q, Hall CE, Barrett KM, Barsan W, et al.; Neurological Emergencies Treatment Trials Network and the SHINE Trial Investigators. Intensive vs standard treatment of hyperglycemia and functional outcome in patients with acute ischemic stroke: the SHINE randomized clinical trial. JAMA 2019;322:326-335

120. Josephson SA, Dillon WP, Smith WS. Incidence of contrast nephropathy from cerebral CT angiography and CT perfusion imaging. Neurology 2005;64:1805-1806

121. Krol AL, Dzialowski I, Roy J, Puetz V, Subramaniam S, Coutts SB, et al. Incidence of radiocontrast nephropathy in patients undergoing acute stroke computed tomography angiography. Stroke 2007;38:2364-2366

122. Hopyan JJ, Gladstone DJ, Mallia G, Schiff J, Fox AJ, Symons SP, et al. Renal safety of CT angiography and perfusion imaging in the emergency evaluation of acute stroke. AJNR Am J Neuroradiol 2008;29:1826-1830

123. Prasad V, Gandhi D, Stokum C, Miller T, Jindal G. Incidence of contrast material-induced nephropathy after neuroendovascular procedures. Radiology 2014;273:853-858

124. Covic A, Schiller A, Mardare NG, Petrica L, Petrica M, Mihaescu A, et al. The impact of acute kidney injury on short-term survival in an Eastern European population with stroke. Nephrol Dial Transplant 2008;23:2228-2234

125. Tsagalis G, Akrivos T, Alevizaki M, Manios E, Theodorakis M, Laggouranis $A$, et al. Long-term prognosis of acute kidney injury after first acute stroke. Clin J Am Soc Nephrol 2009;4:616-622

126. Tsagalis G, Akrivos T, Alevizaki M, Manios E, Stamatellopoulos K, Laggouranis A, et al. Renal dysfunction in acute stroke: an independent predictor of long-term all combined vascular events and overall mortality. Nephrol Dial Transplant 2009;24:194-200

127. Rowe AS, Hawkins B, Hamilton LA, Ferrell A, Henry J, Wiseman $B F$, et al. Contrast-induced nephropathy in ischemic stroke patients undergoing computed tomography angiography: CINISter study. J Stroke Cerebrovasc Dis 2019;28:649-654

128. McCullough PA, Wolyn R, Rocher LL, Levin RN, O'Neill WW. Acute renal failure after coronary intervention: incidence, risk factors, and relationship to mortality. Am J Med 1997;103:368375

129. Rihal CS, Textor SC, Grill DE, Berger PB, Ting HH, Best PJ, et al. Incidence and prognostic importance of acute renal failure after percutaneous coronary intervention. Circulation 2002;105:22592264
130. Gruberg L, Mintz GS, Mehran R, Gangas G, Lansky AJ, Kent KM, et al. The prognostic implications of further renal function deterioration within $48 \mathrm{~h}$ of interventional coronary procedures in patients with pre-existent chronic renal insufficiency. J Am Coll Cardiol 2000;36:1542-1548

131. Marenzi G, Assanelli E, Campodonico J, Lauri G, Marana I, De Metrio $\mathrm{M}$, et al. Contrast volume during primary percutaneous coronary intervention and subsequent contrast-induced nephropathy and mortality. Ann Intern Med 2009;150:170-177

132. Loh Y, McArthur DL, Vespa P, Shi ZS, Liebeskind DS, Jahan R, et al. The risk of acute radiocontrast-mediated kidney injury following endovascular therapy for acute ischemic stroke is low. AJNR Am J Neuroradiol 2010;31:1584-1587

133. Sharma J, Nanda A, Jung RS, Mehta S, Pooria J, Hsu DP. Risk of contrast-induced nephropathy in patients undergoing endovascular treatment of acute ischemic stroke. J Neurointerv Surg 2013:5:543-545

134. Diprose WK, Sutherland L, Wang MTM, Barber PA. Contrast-associated acute kidney injury in endovascular thrombectomy patients with and without baseline renal impairment. Stroke 2019;50:3527-3531

135. Jia ZY, Wang SX, Zhao LB, Cao YZ, Shi HB, Liu S. Risk of acute kidney injury with consecutive, multidose use of iodinated contrast in patients with acute ischemic stroke. AJNR Am J Neuroradiol 2019:40:652-654

136. Chen YL, Fu NK, Xu J, Yang SC, Li S, Liu YY, et al. A simple preprocedural score for risk of contrast-induced acute kidney injury after percutaneous coronary intervention. Catheter Cardiovasc Interv 2014;83:E8-E16

137. Parfrey P. The clinical epidemiology of contrast-induced nephropathy. Cardiovasc Intervent Radiol 2005;28 Suppl 2:S3-S1 1

138. Stacul F. Reducing the risks for contrast-induced nephropathy. Cardiovasc Intervent Radiol 2005;28 Suppl 2:S12-S18

139. Solomon R, Dumouchel W. Contrast media and nephropathy: findings from systematic analysis and Food and Drug Administration reports of adverse effects. Invest Radio/ 2006;41:651-660

140. Dong M, Jiao Z, Liu T, Guo F, Li G. Effect of administration route on the renal safety of contrast agents: a meta-analysis of randomized controlled trials. J Nephro/ 2012;25:290-301

141. Han XF, Zhang XX, Liu KM, Tan H, Zhang Q. Contrast-induced nephropathy in patients with diabetes mellitus between iso- and low-osmolar contrast media: a meta-analysis of fulltext prospective, randomized controlled trials. PLoS One 2018;13:e0194330

142. Toprak O. Risk markers for contrast-induced nephropathy. Am J Med Sci 2007;334:283-290 
143. Calvin AD, Misra S, Pflueger A. Contrast-induced acute kidney injury and diabetic nephropathy. Nat Rev Nephrol 2010;6:679688

144. Heyman SN, Rosenberger C, Rosen S, Khamaisi M. Why is diabetes mellitus a risk factor for contrast-induced nephropathy? Biomed Res Int 2013;2013:123589

145. Wichmann JL, Katzberg RW, Litwin SE, Zwerner PL, De Cecco CN, Vogl TJ, et al. Contrast-induced nephropathy. Circulation 2015;132:1931-1936

146. Liu LY, Liu Y, Wu MY, Sun YY, Ma FZ. Efficacy of atorvastatin on the prevention of contrast-induced acute kidney injury: a meta-analysis. Drug Des Devel Ther 2018;12:437-444

147. Dirnagl U, ladecola C, Moskowitz MA. Pathobiology of ischaemic stroke: an integrated view. Trends Neurosci 1999;22:391397

148. Shuaib A, Lees KR, Lyden P, Grotta J, Davalos A, Davis SM, et al.; SAINT II Trial Investigators. NXY-059 for the treatment of acute ischemic stroke. N Engl J Med 2007;357:562-571

149. Hill MD, Goyal M, Menon BK, Nogueira RG, McTaggart RA, Demchuk AM, et al.; ESCAPE-NA1 Investigators. Efficacy and safety of nerinetide for the treatment of acute ischaemic stroke (ES(APE-NA1): a multicentre, double-blind, randomised controlled trial. Lancet 2020;395:878-887

150. Hong JM, Choi MH, Sohn SI, Hwang YH, Ahn SH, Lee YB, et al.; on the behalf of the SONIC investigators. Safety and Optimal Neuroprotection of Neu2000 in acute Ischemic stroke with reCanalization: study protocol for a randomized, double-blinded, placebo-controlled, phase-II trial. Trials 2018;19:375

151. Lyden P, Hemmen T, Grotta J, Rapp K, Ernstrom K, Rzesiewicz T, et al.; Collaborators. Results of the ICTUS 2 trial (intravascular cooling in the treatment of stroke 2). Stroke 2016;47:2888-2895

152. Neugebauer H, Schneider H, Bösel J, Hobohm C, Poli S, Kollmar $\mathrm{R}$, et al. Outcomes of hypothermia in addition to decompressive hemicraniectomy in treatment of malignant middle cerebral artery stroke: a randomized clinical trial. JAMA Neurol 2019;76:571-579

153. Hong JM, Lee JS, Song HJ, Jeong HS, Choi HA, Lee K. Therapeutic hypothermia after recanalization in patients with acute ischemic stroke. Stroke 2014;45:134-140

154. Marshall JW, Duffin KJ, Green AR, Ridley RM. NXY-059, a free radical--trapping agent, substantially lessens the functional disability resulting from cerebral ischemia in a primate species. Stroke 2001;32:190-198

155. Lees KR, Zivin JA, Ashwood T, Davalos A, Davis SM, Diener HC, et al.; Stroke-Acute Ischemic NXY Treatment (SAINT I) Trial Investigators. NXY-059 for acute ischemic stroke. N Engl J Med

\section{6;354:588-600}

156. Stroke Therapy Academic Industry Roundtable (STAIR). Recommendations for standards regarding preclinical neuroprotective and restorative drug development. Stroke 1999;30:2752-2758

157. Fisher M, Feuerstein G, Howells DW, Hurn PD, Kent TA, Savitz SI, et al.; STAIR Group. Update of the stroke therapy academic industry roundtable preclinical recommendations. Stroke 2009;40:2244-2250

158. Lee JS, Hong JM, Kim EJ, Shin DH, Joo IS, Lim YC, et al. Comparison of the incidence of parenchymal hematoma and poor outcome in patients with carotid terminus occlusion treated with intra-arterial urokinase alone or with combined IV rtPA and intra-arterial urokinase. AJNR Am J Neuroradiol 2012;33:175-179

159. Lee JS, Hong JM, Lee SJ, Joo IS, Lim YC, Kim SY. The combined use of mechanical thrombectomy devices is feasible for treating acute carotid terminus occlusion. Acta Neurochir (Wien) 2013;155:635-641

160. Eom Yl, Hwang YH, Hong JM, Choi JW, Lim YC, Kang DH, et al. Forced arterial suction thrombectomy with the penumbra reperfusion catheter in acute basilar artery occlusion: a retrospective comparison study in 2 Korean university hospitals. AJNR Am J Neuroradiol 2014;35:2354-2359

161. Aarts M, Liu Y, Liu L, Besshoh S, Arundine M, Gurd JW, et al. Treatment of ischemic brain damage by perturbing NMDA receptor- PSD-95 protein interactions. Science 2002;298:846-850

162. Sun HS, Doucette TA, Liu Y, Fang Y, Teves L, Aarts M, et al. Effectiveness of PSD95 inhibitors in permanent and transient focal ischemia in the rat. Stroke 2008;39:2544-2553

163. Hill MD, Martin RH, Mikulis D, Wong JH, Silver FL, Terbrugge KG, et al.; ENACT trial investigators. Safety and efficacy of NA-1 in patients with iatrogenic stroke after endovascular aneurysm repair (ENACT): a phase 2, randomised, double-blind, placebo-controlled trial. Lancet Neurol 2012;11:942-950

164. Slomski A. Alteplase inhibits nerinetide, a novel stroke drug. JAMA 2020;323:1543

165. Baron JC. Nerinetide: a potential neuroprotectant as adjunct to thrombectomy for acute stroke. Can J Neurol Sci 2021:48:138

166. Gwag BJ, Lee YA, Ko SY, Lee MJ, Im DS, Yun BS, et al. Marked prevention of ischemic brain injury by Neu2000, an NMDA antagonist and antioxidant derived from aspirin and sulfasalazine. J Cereb Blood Flow Metab 2007;27:1142-1151

167. Im DS, Jeon JW, Lee JS, Won SJ, Cho SI, Lee YB, et al. Role of the NMDA receptor and iron on free radical production and brain damage following transient middle cerebral artery occlusion. Brain Res 2012;1455:114-123

168. Polderman KH. Mechanisms of action, physiological effects, 
and complications of hypothermia. Crit Care Med 2009;37(7 Suppl):S186-S202

169. Erecinska M, Thoresen M, Silver IA. Effects of hypothermia on energy metabolism in Mammalian central nervous system. J Cereb Blood Flow Metab 2003;23:513-530

170. Bernard SA, Gray TW, Buist MD, Jones BM, Silvester W, Gutteridge $G$, et al. Treatment of comatose survivors of out-of-hospital cardiac arrest with induced hypothermia. N Engl J Med 2002;346:557-563

171. Hypothermia after Cardiac Arrest Study Group. Mild therapeutic hypothermia to improve the neurologic outcome after cardiac arrest. N Engl J Med 2002;346:549-556
172. Callaway CW, Donnino MW, Fink EL, Geocadin RG, Golan E, Kern KB, et al. Part 8: post-cardiac arrest care: 2015 American Heart Association guidelines update for cardiopulmonary resuscitation and emergency cardiovascular care. Circulation 2015;132(18 Suppl 2):S465-S482

173. Kuczynski AM, Demchuk AM, Almekhlafi MA. Therapeutic hypothermia: applications in adults with acute ischemic stroke. Brain Circ 2019;5:43-54

174. Piironen K, Tiainen M, Mustanoja S, Kaukonen KM, Meretoja A, Tatlisumak T, et al. Mild hypothermia after intravenous thrombolysis in patients with acute stroke: a randomized controlled trial. Stroke 2014:45:486-491 